\title{
Platinum-group element geochemistry of the Escondida igneous suites, Northern Chile: implications for ore
}

formation

Hongda Hao ${ }^{1,2 *}$, Ian H. Campbell ${ }^{1}$, Jeremy P. Richards ${ }^{2}$, Eizo Nakamura ${ }^{3}$ and Chie Sakaguchi ${ }^{3}$

${ }^{1}$ Research School of Earth Sciences, Australian National University, Canberra, ACT 2601, Australia; ${ }^{2}$ Mineral Exploration Research Centre, Harquail School of Earth Sciences, Laurentian University, Sudbury, Ontario P3E 2C6, Canada; ${ }^{3}$ The Pheasant Memorial Laboratory (PML), Institute for Planetary Materials, Okayama University, Misasa, Tottori 682-903, Japan

*Corresponding author. E-mail: hongda.hao@anu.edu.au 


\section{ABSTRACT}

Platinum-group element (PGE) geochemistry may be used to constrain the timing of sulfide saturation in magmas, which influences $\mathrm{Cu}$ and $\mathrm{Au}$ fertility of evolving magmatic systems. We report new geochronological and geochemical analyses, with emphasis on PGE geochemistry, for a suite of regional hornblende-porphyritic diorite intrusions and ore-bearing porphyries from the super-giant Escondida and smaller Zaldivar $\mathrm{Cu}$ deposits of Northern Chile. The regional dioritic intrusions have zircon $\mathrm{U}-\mathrm{Pb}$ ages between 39.6 to $37.1 \mathrm{Ma}$, which overlap with ages of ore-bearing Escondida and Zaldivar porphyries (38.1 to 35.0 Ma). Whole rock major and trace element, $\mathrm{Sr}-\mathrm{Nd}-\mathrm{Pb}$ and zircon $\mathrm{O}-\mathrm{Hf}$ isotope geochemistry indicates that the regional diorites and ore-bearing porphyries are co-magmatic and originated from the same mantle-derived magma by fractional crystallization, with minor contamination by Paleozoic crust $(\sim 10 \%)$. The low concentrations of PGE in the regional diorites show that they reached sulfide saturation before the $\mathrm{MgO}$ content of the melt fell to $4.7 \mathrm{wt} \%$, the $\mathrm{MgO}$ content of the most primitive sample analysed. The fraction of sulfide melt to precipitate from the melt that formed regional diorites is estimated to be $\sim 0.12 \mathrm{wt} . \%$, which resulted in partitioning of highly chalcophile elements (Au and PGE) into a sulfide phase that was retained in cumulus rocks at depth. However, the fraction of sulfide to precipitate was too low to have a significant effect on the $\mathrm{Cu}$ content of the fractionating melt. As a consequence, when the evolving melt eventually reached volatile saturation, it contained enough $\mathrm{Cu}(40 \pm$ $10 \mathrm{ppm}$ ) to form a super-giant $\mathrm{Cu}$ deposit. In contrast, Au was largely stripped from the melt by sulfide precipitation, with the result that the mineralization at Escondida is $\mathrm{Cu}$ dominant with only minor Au. The Zaldivar deposit, on the other hand, contains even less $\mathrm{Au}$, which is attributed to a longer fractionation interval between sulfide and volatile saturation. This study provides evidence to support previously proposed models, which suggest that the timing of sulfide saturation, the amount of sulfide melt to precipitate, the water content and oxidation 
state of the melt, and the magma volume are critical factors in determining the potential to form a porphyry $\mathrm{Cu}$ deposit. Plots of $\mathrm{Pd} / \mathrm{MgO}$ against $\mathrm{Y}$ can be used as empirical indicators of magma fertility for porphyry mineralization, and to discriminate between $\mathrm{Cu}-\mathrm{Au}$ and $\mathrm{Cu}$ dominated systems, but cannot predict the size of the deposit. The super-giant status of the Escondida deposit is attributed to it being underlain by a large batholith with a calculated minimum mass of $10^{12}$ tonnes $\left(\sim 400 \mathrm{~km}^{3}\right)$.

Key words: Escondida; Platinum-group elements; Sulfide saturation; Porphyry deposits

\section{INTRODUCTION}

Porphyry deposits, the world's most important source of $\mathrm{Cu}$, $\mathrm{Au}$ and $\mathrm{Mo}$, are generally associated with continental or oceanic arc magmas of intermediate to felsic composition (Burnham, 1979; Richards, 2003; Cooke et al., 2005; Sillitoe, 2010). Processes that control the formation of porphyry mineralization include: the metal endowment of the primitive magma (McInnes et al., 1999; Mungall, 2002; Richards, 2011a; Audétat and Simon, 2012); the oxidation state during magmatic evolution (Candela, 1992; Richards, 2003, 2015; Sillitoe, 2010); the water content of the magma (Burnham, 1979; Candela, 1992; Richards, 2003, 2011b, 2012); the timing of sulfide saturation relative to volatile exsolution (Richards, 2003; Cocker et al., 2015; Hao et al., 2017; Lowczak et al., 2018); the metal content of the magma at the time of volatile exsolution (Jenner et al., 2010; Park et al., 2015); and the efficiency of the hydrothermal fluid, released by the magma, to dissolve, transport, and precipitate ore metals (Cline and Bodnar, 1991; Candela and Piccoli, 2005; Wilkinson, 2013). In this paper, we focus on the petrogenesis and evolution of porphyry magma systems, emphasizing the relative timing of sulfide and volatile saturation and their roles in determining magma fertility. 
Recent studies (Cocker et al., 2015; Hao et al., 2017; Lowczak et al., 2018) have used platinum-group element (PGE) geochemistry to argue that the relationship between sulfide and volatile saturation plays a critical role in determining magma fertility (i.e., the potential of a given magma system to produce a hydrothermal ore deposit). The results of initial studies (Cocker et al., 2015; Hao et al., 2017) are consistent with the hypothesis that if fluid exsolution occurs before, or shortly after sulfide saturation, $\mathrm{Cu}$ and/or $\mathrm{Au}$ will be available to enter the hydrothermal fluid, potentially resulting in the formation of a porphyry $\mathrm{Cu} \pm \mathrm{Au}$ deposit (Spooner, 1993). Alternatively, if the magma reaches sulfide saturation well before volatile saturation, $\mathrm{Cu}, \mathrm{Au}$, and other highly chalcophile elements such as platinum-group elements (PGE) will be trapped in sulfide phases in the cumulate pile of a deep magma chamber, assumed to underlie the porphyry system, where they will be unavailable to enter the hydrothermal fluid (Mitchell and Keays, 1981; Hamlyn et al., 1985; Peach et al., 1990; Li and Audétat, 2015).

Platinum-group elements have been used to identify the onset of sulfide saturation in magmas in preference to $\mathrm{Au}$ and $\mathrm{Cu}$ for two reasons: first, their partition coefficients into immiscible sulfide melts are at least one or two orders of magnitude higher than those of $\mathrm{Au}$ and $\mathrm{Cu}$, respectively, making them more sensitive indicators of sulfide saturation; second, they are appreciably less mobile than $\mathrm{Cu}$ and $\mathrm{Au}$ in the alteration haloes associated with ore formation, and therefore better preserve the original igneous geochemistry of the associated intrusions (Park et al., 2016).

Candela (1992), Mungall (2002), Richards (2003), Candela and Piccoli (2005), and Sun et al. (2015) have argued that a high oxidation state of the magma delays sulfide saturation and favours the formation of porphyry deposits. Early magnetite crystallization, on the other hand, which removes $\mathrm{Fe}^{3+}$ from the melt and lowers its $f \mathrm{O}_{2}$, promotes early sulfide saturation (Jenner et al., 2010; Keays and Tegner, 2015) and is likely to be unfavourable. The 
water content of the melt is also important because high water concentrations favour volatile exsolution, which is essential for porphyry mineralization (Burnham, 1979; Candela, 1992; Spooner, 1993; Richards, 2003, 2011b, 2012).

The Escondida district (Figs. 1 and 2), which includes the giant Escondida and smaller Zaldivar porphyry $\mathrm{Cu}$ deposits, and several regional dioritic intrusions (Richards et al., 1999, 2001; Padilla Garza et al., 2001), provides an excellent opportunity to test hypotheses for the roles of relative timing of sulfide and volatile saturation in determining the fertility of felsic magma systems. Escondida is the world's largest $\mathrm{Cu}$ producer (The World Copper Factbook 2017; measured resource of 5,350 Mt at $0.63 \%$ Cu; BHP Annual Report, 2017) and it produces $\mathrm{Au}$ and $\mathrm{Ag}$ as by-products, whereas the smaller Zaldivar deposit produces little gold (measured and indicated resource of $604.2 \mathrm{Mt}$ at $0.48 \% \mathrm{Cu}$; Antofagasta plc., Annual Report and Financial Statements 2017). All of the ore-bearing porphyries and regional dioritic intrusions studied in this project are of similar age ( 38-35 Ma; Richards et al., 1999, 2001) and lie within $\sim 15 \mathrm{~km}$ of the Escondida mine (see Escondida regional map from Richards et al., 2001, and Fig. 2).

We present the results of zircon $\mathrm{U}-\mathrm{Pb}$ geochronology, whole rock major, trace element (including PGE), and $\mathrm{Sr}-\mathrm{Nd}-\mathrm{Pb}$ isotope analyses, and zircon $\mathrm{Hf}-\mathrm{O}$ isotope analyses for both the ore-bearing porphyries and regional diorites. We show that they are co-magmatic and use PGE geochemistry to demonstrate early sulfide saturation in the regional diorites. However, the fraction of segregated immiscible sulfide melt was low and had little effect on the $\mathrm{Cu}$ content of the evolving silicate melt, so that when it eventually became volatile saturated it still contained enough $\mathrm{Cu}$ to form the Escondida and Zaldivar $\mathrm{Cu}$ deposits. 


\section{REGIONAL AND DEPOSIT GEOLOGY}

The Escondida porphyry $\mathrm{Cu}$ deposit is located in northern Chile (Fig. 1), near the eastern border of the Cordillera de Domeyko, which is the third of five north-south-trending morphotectonic-physiographic belts (west to east: Coastal Range, Central Depression, Cordillera de Domeyko, Preandean Basin, and Andean Cordillera; Sillitoe and McKee, 1996; Padilla Garza et al., 2001). The Cordillera de Domeyko basement is genetically linked to the formation of the western margin of Gondwana during the Paleozoic (Ramos, 1989), which represents the earliest stage of its evolution. The geology of the Escondida district includes intermediate to felsic Permo-Carboniferous volcanic rocks, Late Triassic andesitic and rhyolitic volcanic rocks, Jurassic to Cretaceous sedimentary and intercalated volcanic rocks, Cretaceous monzonite and gabbro intrusions, Paleocene to early Eocene andesitic and felsic volcanic rocks intercalated with arenaceous and calcareous sedimentary rocks, late Eocene to early Oligocene dioritic and mineralized porphyry intrusions, and Miocene to Quaternary gravel deposits (Richards et al., 2001; Hervé et al., 2012).

The regional structure is dominated by the north-south strike-slip West Fissure Fault Zone, which is part of the Domeyko fault system and is associated with many other large porphyry $\mathrm{Cu}$ deposits in northern Chile including, from north to south, Collahuasi, El Abra, Chuquicamata, Escondida, and El Salvador (Fig. 1; Reutter et al., 1996; Cornejo et al., 1997; Garza et al., 2001; Ossandón et al., 2001; Richards et al., 1999, 2001; Masterman et al., 2005; Urqueta et al., 2009; Cocker et al., 2015). The key structural features of the Escondida district are a series of north-south-striking left-lateral strike-slip faults that have a sigmoidal shape in the area of mineralization. The Escondida deposit itself is controlled by two north-south faults, the Portezuelo and Panadero faults, which are strands of the West Fissure Fault Zone (Richards et al., 2001; Padilla Garza et al., 2001; Hervé et al., 2012). 
Escondida is a $\mathrm{Cu}$-dominant deposit that also produces $\mathrm{Au}$ and $\mathrm{Ag}$ as byproducts. It has been mined for over thirty years, with a measured sulfide resource of 5,350 Mt at $0.63 \%$ $\mathrm{Cu}$, and an indicated sulfide resource of 3,510 $\mathrm{Mt}$ at $0.57 \% \mathrm{Cu}$ (BHP Annual Report, 2017). Dacitic quartz-feldspar-biotite porphyries, which are associated with the hypogene $\mathrm{Cu}$ mineralization at Escondida, are referred to as the Escondida porphyry ( $\sim 38 \mathrm{Ma}$; Richards et al., 1999, 2001). The Escondida porphyry is intruded by the younger Rhyolitic porphyry $(\sim 35$ Ma; Richards et al., 1999), which introduced weak $\mathrm{Cu}$ mineralization. The Escondida and Rhyolitic porphyries are coeval with regional Late Eocene to early Oligocene dioritic intrusions ( 38 Ma; Richards et al., 1999, 2001). An intrusive body, of batholith dimensions, is interpreted to underlie the Escondida district at shallow depths, based on a large and extensive magnetic anomaly in regional aeromagnetic data (Behn et al., 2001).

Hornblende ${ }^{40} \mathrm{Ar} /{ }^{39} \mathrm{Ar}$ dating of six diorite samples yielded ages between $38.28 \pm 0.32$ and $36.94 \pm 0.46 \mathrm{Ma}$ (Richards et al, 2001). One sample of syn-mineralization Escondida porphyry gave a zircon U-Pb age of 37.9 $\pm 1.1 \mathrm{Ma}$ (Richards et al., 1999), whereas a late Rhyolitic porphyry sample yielded a zircon U-Pb age of $34.7 \pm 1.7 \mathrm{Ma}$ (Richards et al., 1999). Two molybdenite samples from Escondida yielded Re-Os ages of $36.1 \pm 0.2$ and $35.2 \pm 0.2$ Ma (Romero et al., 2011), which are marginally younger than both the diorite intrusions and the Escondida porphyry. They are interpreted to indicate that the molybdenite mineralization occurred at a late stage in the magmatic to hydrothermal transition.

The Zaldivar porphyry copper deposit is a smaller mine located about $5 \mathrm{~km}$ to the north of the Escondida deposit. The Llamo porphyry, a dacitic feldspar-biotite-quartz porphyry $\left(38.7 \pm 1.3 \mathrm{Ma}\right.$, zircon $\mathrm{U}-\mathrm{Pb}$ age; $37.40 \pm 0.18 \mathrm{Ma}$, biotite ${ }^{40} \mathrm{Ar} /{ }^{39} \mathrm{Ar}$ age $)$, is spatially associated with the ore and is regarded as the source of mineralization (Richards et al., 2001). 


\section{SAMPLES AND ANALYTICAL METHODS}

The samples analysed in this study are from the suite described by Richards et al. (2001) and include regional dioritic intrusions, and the Escondida, Rhyolitic, and Zaldivar Llamo porphyries. Fresh samples were selected where possible, but some weakly altered samples were chosen in the case of the porphyries. Five hundred grams to $2000 \mathrm{~g}$ of rock, which had already been crushed to $1-2 \mathrm{~cm}$ chips, were ground to a fine powder in a case hardened soft iron mill. The sample numbers used in this study are from those of Richards et al. (2001) and the locations are given in Figure 2 and Supplementary Data Table A1.

\section{Whole-rock major and trace element analyses}

Whole-rock major oxides were analysed in two samples (ESC2 and ZAL4) by X-Ray fluorescence (XRF) spectrometry at Intertek Genalysis Laboratory, Australia, using the fusion method (Morris et al., 2015). International reference materials (SARM1 and SARM2) were measured with the unknown samples for quality control, and results are listed in Supplementary Data Table A2. Analyses of other samples are listed in Richards et al. (2001).

The trace-element concentrations were measured in 15 samples by laser ablation (LA)inductively coupled plasma-mass spectrometry (ICP-MS) at the Australian National University (ANU). Half a gram of sample powder was mixed with $1.5 \mathrm{~g}$ of flux, which consisted of $65 \%$ lithium metaborate and $35 \%$ lithium tetraborate, and fused in an induction furnace to make a glass disk for LA-ICP-MS analyses. The LA-ICP-MS analytical system consists of a Lambda Physic Complex 110 excimer laser $(\lambda=193 \mathrm{~nm})$, an ANU-designed HelEx ablation cell, and an Agilent 7700 ICP-MS. The analyses were obtained using a spot size of $105 \mu \mathrm{m}$ and a laser pulse rate of $5 \mathrm{~Hz}$. Each spot analysis consisted of $25 \mathrm{~s}$ of background measurement and $40 \mathrm{~s}$ of sample ablation. After every ten unknown analyses, 
BCR-2g glass (USGS) was measured as primary standard, and the NIST 610 and 612 glasses (Jochum et al., 2011) were measured for quality control. The Iolite software package (Paton et al., 2011) was used for data reduction with Ca as internal standard. Analytical uncertainty, represented by the relative standard deviation of multiple analyses of NIST 610 and 612, is less than $3 \%$ relative $(1 \sigma)$ for all elements (Supplementary Data Table A3).

\section{Whole-rock PGE and Re analyses}

Platinum-group element and Re concentrations were measured on all the samples that were selected for trace-element analyses, using the $\mathrm{Ni}$-sulfide fire assay-isotope dilution method described by Park et al. (2012a). An Agilent 7700 x quadrupole ICP-MS system at ANU was used for the measurements, and the sensitivities during each analytical session were 1.2 to 2.8 x $10^{5}$ c.p.s. ppb $^{-1}$ for masses 89,140 and 205. Seven selected samples were analysed in duplicate to assess heterogeneity. The measured isotope ratios, used to calculate the concentrations of Ir, Ru, Pt, Pd and Re, were ${ }^{191} \mathrm{Ir} /{ }^{193} \mathrm{Ir},{ }^{99} \mathrm{Ru} /{ }^{101} \mathrm{Ru},{ }^{195} \mathrm{Pt} /{ }^{194} \mathrm{Pt},{ }^{105} \mathrm{Pd} /{ }^{108} \mathrm{Pd}$, and ${ }^{185} \mathrm{Re} /{ }^{187} \mathrm{Re}$, respectively. The method described by Meisel et al. (2003) was used to measure the mono-isotopic element Rh from the ratio of the count rates for ${ }^{103} \mathrm{Rh}$ and ${ }^{106} \mathrm{Pd}$, assuming the Rh loss was similar to the Pd loss during the analytical procedure. The atomic amount of ${ }^{103} \mathrm{Rh}$ in the sample and spike mixture $\left(\mathrm{N}_{\text {mix }}^{103} \mathrm{Rh}\right)$ is calculated as follows:

$\mathrm{N}_{\text {mix }}^{103} \mathrm{Rh}=\mathrm{N}_{\text {mix }}^{106} \mathrm{Pd} \times \frac{\mathrm{C}_{\text {mix }}^{103}}{\mathrm{C}_{\text {mix }}^{106}} \times \frac{\mathrm{C}_{\text {standard }}^{103}}{\mathrm{C}_{\text {standard }}} \times \frac{\mathrm{N}_{\text {standard }}^{106} \mathrm{Rh}}{\mathrm{N}_{\text {standard }}^{106} \mathrm{Pd}}$ where $\mathrm{N}_{\text {standard }}^{\mathrm{A}}$ and $\mathrm{N}_{\text {mix }}^{\mathrm{A}}$ are the atomic amounts of the isotope $\mathrm{A}$ in the standard and sample + spike mixture, respectively. $\mathrm{C}_{\text {standard }}^{\mathrm{A}}$ and $\mathrm{C}_{\text {mix }}^{\mathrm{A}}$ are the count rates of isotope $\mathrm{A}$ in the standard and sample + spike mixture, respectively. 
Potential molecular interferences on the analysed isotopes, which resulted from $\mathrm{Ni}, \mathrm{Cu}$, $\mathrm{Zn}, \mathrm{Co}, \mathrm{Hf}, \mathrm{Mo}, \mathrm{Zr}$ and Ta argides or oxides, were monitored by measuring solutions containing these interference elements. The solutions were measured during the analytical session and the count rate for each interference element was divided by the count of the PGE, which is introduced by the isotopes of this element + argide or oxide, to calculate the relative argide and oxide production rates. Argide and oxide production rates were from $0.001 \%$ to $0.002 \%$ and from $0.03 \%$ to $0.7 \%$, respectively. The interference corrections were $<0.7 \%$ for most of the Rh, Pt, Pd and Re analyses, and $<2 \%$ for most of the Ir analyses. However, the mineralized samples have relatively high interference corrections. Two samples (ESC1 and ESC3 and their duplicates) have interference corrections of 2 to $26 \%$ for Pd analyses, respectively, and the Zaldivar Llamo porphyry (ZAL1 and ZAL4) has an interference of ca. 110\% from Mo-oxide on Pd. Seven Rh analyses (ESC3 and ZAL4 and their duplicates, ESC2-duplicate, ESC2-duplicate2 and ZAL1-duplicate) have interference corrections of 3 to $20 \%$, one analysis (ZAL1) has a Cu-oxide interference of $75 \%$ on $\mathrm{Rh}$, and two analyses of $\mathrm{Ir}$ (IM151 and ZAL1) have interference corrections of 4\% and 8\%. The interference corrections for $\mathrm{Ru}$ are generally less than $50 \%$ except for two analyses of IM90 and ZAL1, which required corrections of $66 \%$ and $97 \%$, respectively.

Average procedure blanks, which were determined from four sample-free analyses, were 3.6 pg for Ir, 24.6 pg for Ru, 7.1 pg for Rh, 152.8 pg for Pt, 95.9 pg for Pd and 117.4 pg for Re, which is equivalent to $0.7 \mathrm{ppt}$ for $\mathrm{Ir}, 4.9 \mathrm{ppt}$ for $\mathrm{Ru}, 1.4 \mathrm{ppt}$ for $\mathrm{Rh}, 30.6 \mathrm{ppt}$ for $\mathrm{Pt}$, 19.2 ppt for Pd and 23.5 ppt for Re, based on a sample size of $5 \mathrm{~g}$ (Table 1). The method detection limit (MDL), taken to be three standard deviations of procedure blanks, were $0.3 \mathrm{ppt}$ for Ir, 5.5 ppt for Ru, 1.6 ppt for Rh, $40.8 \mathrm{ppt}$ for Pt, 17.2 ppt for Pd and $18.4 \mathrm{ppt}$ for Re. The accuracy and precision of the analyses were tested by performing four replicate analyses on the reference material TDB-1 (CANMET diabase). The results are consistent with the data 
from previous studies (Table 1; Peucker-Ehrenbrink et al., 2003; Meisel and Moser, 2004; Park et al., 2012a, b, 2013a, b, 2015; Hao et al., 2017; GeoRem database; Table 1).

\section{Sr-Nd-Pb isotopic analyses}

$\mathrm{Sr}-\mathrm{Nd}-\mathrm{Pb}$ isotopic analyses were carried out on a Finnigan-Triton thermal ionization mass spectrometer (TIMS) equipped with nine Faraday cups at the Pheasant Memorial Laboratory, Institute for Planetary Materials, Okayama University. The analytical procedure followed the methods described by Yoshikawa and Nakamura (1993) for Sr, Nakamura et al. (2003) for Nd and Kuritani and Nakamura (2002) and Nakamura et al. (2003) for Pb (double spike method). Magnesium solution was added to the samples prior to acid digestion to suppress the formation of $\mathrm{AlF}_{3}$, which can incorporate some trace elements $(\mathrm{Rb}, \mathrm{Sr}, \mathrm{Y}, \mathrm{Cs}, \mathrm{Ba}, \mathrm{REE}, \mathrm{Pb}$, Ta and U; Takei et al., 2001). The nine selected Escondida samples were analysed in one batch as part of an analytical session that included two other batches from another study, and the results of the reference solution and rock samples are consistent within the analytical session (Supplementary Data Table A4).

The measured ${ }^{87} \mathrm{Sr} /{ }^{86} \mathrm{Sr}$ values of Sr reference solution NIST987 and rock sample JB-2 were $0.710281 \pm 13(n=10,2 \sigma)$, and $0.703705 \pm 5(n=4,2 \sigma)$, respectively. Strontium isotope mass fractionation was corrected using ${ }^{86} \mathrm{Sr} /{ }^{88} \mathrm{Sr}=0.1194$. The measured in-house reference solution PML-Nd yielded a ${ }^{143} \mathrm{Nd} /{ }^{144} \mathrm{Nd}$ of $0.511729 \pm 26(\mathrm{n}=9,2 \sigma)$, which is equivalent to an average of ${ }^{143} \mathrm{Nd} /{ }^{144} \mathrm{Nd}=0.511865$ for the La Jolla standard reference material, and the reference rock sample JB-2 yielded a ${ }^{143} \mathrm{Nd} /{ }^{144} \mathrm{Nd}$ value of $0.513122 \pm 12(\mathrm{n}$ $=4,2 \sigma)$. The $\mathrm{Nd}$ isotope mass fractionation was corrected using ${ }^{146} \mathrm{Nd} /{ }^{144} \mathrm{Nd}=0.7219$, and the present-day chondrite uniform reservoir (CHUR) ${ }^{143} \mathrm{Nd} /{ }^{144} \mathrm{Nd}$ ratio used to calculate $\varepsilon \mathrm{Nd}$ is 0.512638 (Goldstein et al., 1984). The total average procedure blanks for $\mathrm{Sr}$ and Nd were 
75 and 610 pg, respectively (Supplementary Data Table A5), which was relatively high due to high $\mathrm{Sr}$ and $\mathrm{Nd}$ in the $\mathrm{Mg}$-solution $(0.35-0.40 \mathrm{ml})$ added to supress $\mathrm{AlF}_{3}$ formation (Supplementary Data Table A6). However, the effects of Mg-solution on the samples were less than 0.0003 and $0.05 \%$ for the absolute concentration of $\mathrm{Sr}$ and $\mathrm{Nd}$, respectively; isotopic corrections were negligible (Supplementary Data Table A6).

The measured average ratios of Pb reference solution of NBS981 were $16.942 \pm$ 0.003 for ${ }^{206} \mathrm{~Pb} /{ }^{204} \mathrm{~Pb}, 15.499 \pm 0.004$ for ${ }^{207} \mathrm{~Pb} /{ }^{204} \mathrm{~Pb}$, and $36.727 \pm 0.010$ for ${ }^{208} \mathrm{~Pb} /{ }^{204} \mathrm{~Pb}(\mathrm{n}$ $=9,2 \sigma)$. The replicated analyses of reference rock sample JB-3 yielded ${ }^{206} \mathrm{~Pb} /{ }^{204} \mathrm{~Pb}$ of 18.296 $\pm 0.003,{ }^{207} \mathrm{~Pb} /{ }^{204} \mathrm{~Pb}$ of $15.539 \pm 0.002$, and ${ }^{208} \mathrm{~Pb} /{ }^{204} \mathrm{~Pb}$ of $38.256 \pm 0.006(\mathrm{n}=8,2 \sigma)$. The total average procedure blank of $\mathrm{Pb}$ was $11 \mathrm{pg}$ (Supplementary Data Table A5).

\section{Zircon analyses}

Zircon grains were separated from whole rock samples by standard crushing, heavy liquid and magnetic separation procedures. Hand picked sample zircons and reference zircon grains for oxygen isotope and U-Pb dating analyses (TEMORA II, FC1, MUDTANK and R33) were annealed at $900^{\circ} \mathrm{C}$ for $48 \mathrm{~h}$ in air to eliminate the alpha-dose-induced differences in ablation characteristics when measuring ${ }^{206} \mathrm{~Pb} /{ }^{238} \mathrm{U}$ (Allen and Campbell, 2012). Unknown zircons and standards (TEMORA II, FC1, MUDTANK and R33) were set in epoxy resin mounts and polished. Reflected and transmitted light photography and cathodoluminescence (CL) images were prepared to assist with selection of spots for analyses by sensitive high-resolution iron microprobe (SHRIMP) and LA-ICP-MS.

Zircon oxygen isotopes were analysed by SHRIMP II at ANU with a spot size of $c .20$ $\mu \mathrm{m}$. Analytical conditions and measurement procedures were similar to those described by Ireland and Williams (2003) and Ickert et al. (2008). The Temora II zircon standard was 
analysed after every 4 analyses of unknown zircons to correct for instrumental mass fractionation, assuming $\delta^{18} \mathrm{O}_{\mathrm{VSMOW}}=8.2 \%$ (Valley, 2003; Valley et al., 2005; Black et al., 2004). Reproducibility, obtained from replicate analyses of the Temora II zircon standard, was $0.25 \%, 0.32 \%$ and $0.44 \%$ o $(2 \sigma)$, respectively, for the three analytical sessions (Supplementary Data Table A7). The standard zircon MUDTANK was also measured as a secondary standard to monitor data quality. The average results were $4.92 \pm 0.39 \%$ o $(n=7$, $2 \sigma), 5.11 \pm 0.46 \%(n=10,2 \sigma)$ and $5.21 \pm 0.58 \%(n=20,2 \sigma)$ for the three analytical sessions, respectively (Supplementary Data Table A7), which lie within uncertainty of the reference values (5.03\%; Valley, 2003)

The same LA-ICP-MS technique used for whole-rock trace-element analyses was used to date and analyse trace elements in zircons over three analytical sessions. The spot size used was $28 \mu \mathrm{m}$ and the laser pulse rate was $5 \mathrm{~Hz}$. Analytical times were $25 \mathrm{~s}$ for baseline measurement and $40 \mathrm{~s}$ for sample ablation, which included integration times of $30 \mathrm{~ms}$ for ${ }^{206} \mathrm{~Pb},{ }^{207} \mathrm{~Pb},{ }^{208} \mathrm{~Pb},{ }^{232} \mathrm{Th}$ and ${ }^{238} \mathrm{U}$, and $10 \mathrm{~ms}$ for ${ }^{29} \mathrm{Si},{ }^{31} \mathrm{P},{ }^{49} \mathrm{Ti},{ }^{51} \mathrm{~V},{ }^{91} \mathrm{Zr},{ }^{139} \mathrm{La},{ }^{140} \mathrm{Ce},{ }^{146} \mathrm{Nd}$, ${ }^{153} \mathrm{Eu},{ }^{163} \mathrm{Dy},{ }^{175} \mathrm{Lu}$ and ${ }^{177} \mathrm{Hf}$. The ablation sites were the same as for the $\mathrm{O}$ isotope analyses. The presence of inclusions was identified from the signal intensities of ${ }^{31} \mathrm{P},{ }^{49} \mathrm{Ti}$ and ${ }^{139} \mathrm{La}$, which have high concentrations in apatite and rutile, the most common inclusions in zircon. After 10 unknown analyses, zircon standards TEMORA II and R33 were measured as primary and secondary reference materials, respectively, for U-Pb dating, and the NIST 610 glass (Jochum et al., 2011) as the primary standard for trace element concentrations. Silica was selected as the internal standard and the Iolite software (Paton et al., 2011) was used for data processing. Analytical uncertainties (propagated $2 \sigma$ ) for each spot analysis were calculated by adding the uncertainty in the analysis to the uncertainty of the TEMORA II standard in quadrature. 
After the data were exported from the Iolite software, the amount of common $\mathrm{Pb}$ was determined by the ${ }^{208} \mathrm{~Pb}$ method (Compston et al., 1984) and the calculated amount subtracted, assuming a common $\mathrm{Pb}$ composition obtained from the age dependent $\mathrm{Pb}$ model of Cumming and Richards (1975). Cumulative probability plots, obtained from the ISOPLOT software of Ludwig (2012), were used to objectively identify zircons that did not belong to the dominant age population. Zircons that lie above or below the linear array produced by the dominant age population were considered to be inherited grains or grains that have undergone $\mathrm{Pb}$ loss, respectively, and were omitted from the age calculation (Campbell et al., 2006). Zircon grains were considered to be discordant if their ${ }^{208} \mathrm{~Pb}$-corrected ${ }^{206} \mathrm{~Pb} /{ }^{238} \mathrm{U}$ age divided by their ${ }^{208} \mathrm{~Pb}$ corrected ${ }^{207} \mathrm{~Pb} /{ }^{235} \mathrm{U}$ age, was greater than $1 \pm 0.1$ including $1 \sigma$ uncertainties (Cumming and Richards, 1975; Campbell et al., 2006), and were also rejected from the age calculation. The weighted average ${ }^{206} \mathrm{~Pb} /{ }^{238} \mathrm{U}$ ages were calculated using the ISOPLOT software. Multiple analyses of R33, which were used to evaluate the precision and accuracy of the three analytical sessions, gave weighted mean ages ( $\pm 2 \mathrm{se}, 95 \%$ confidence) of $418.4 \pm 3.2 \mathrm{Ma}(\mathrm{n}=$ $28), 415.2 \pm 2.6 \mathrm{Ma}(\mathrm{n}=40)$ and $417.9 \pm 2.2 \mathrm{Ma}(\mathrm{n}=21)$, respectively (Supplementary Data Table A8), which are similar to the ID-TIMS age of 418.9 \pm 0.4 Ma (Black et al., 2004).

Lu-Hf isotopes were measured using a HelEx ArF excimer $(\lambda=193 \mathrm{~nm})$ LA system coupled with a ThermoFinnigan Neptune multiple collector (MC-ICP-MS) at ANU, using methods described by Eggins et al. (2005), Wang et al. (2009) and Hiess et al. (2009). Zircon samples were analysed in two analytical sessions, using a spot size of $39 \mu \mathrm{m}$ with a laser repetition rate of $5 \mathrm{~Hz}$, an ablation time of $60 \mathrm{~s}$, and pre- and post-ablation times of $20 \mathrm{~s}$. The ablation spots for Lu-Hf isotopic analyses were sited as close as possible to the original analytical sites used for the $\mathrm{O}$ isotope and U-Pb dating. Zircon standard 91500 was measured as primary reference, and QGNG, FC1 and MUDTANK (Wiedenbeck et al. 1995; Woodhead et al. 2004; Woodhead and Hergt 2005; Sláma et al. 2008) were measured after 20 analyses 
as secondary standards to monitor the data quality. The data were processed using the Iolite software (Paton et al., 2011), and the averages for the secondary zircon standards, QGNG, FC1 and MUDTANK, are consistent with the reported values (Supplementary Data Table A9).

\section{RESULTS}

\section{Petrography}

The regional diorites contain phenocrysts of plagioclase, clinopyroxene, orthopyroxene, and hornblende (Fig. 3a-d). Abundant primary magnetite, with ilmenite lamellae, is found in all of the diorites (Fig. 3e). Accessory minerals include biotite and apatite (Fig. 3b). Magmatic sulfide inclusions were observed in one diorite sample (IM62) as 10-20 $\mu \mathrm{m}$ spheroidal inclusions in clinopyroxene and plagioclase phenocrysts (Fig. 3h and i). These inclusions are interpreted to be trapped sulfide liquids, and indicate that the dioritic magma was saturated in sulfide during at least part of its history. The diorites crop out within a broad zone of propylitic alteration extending more than $10 \mathrm{~km}$ from the porphyry centres. Least-altered samples were collected in the field, but most show minor chloritization (Fig. 3b).

The ore-bearing porphyry samples contain plagioclase and quartz as the dominant phenocryst phases, and biotite is preserved in some samples (e.g., ZAL1; Fig. 3g). Plagioclase phenocrysts and groundmass are variably altered to sericite and kaolinite in the samples used for this study (Fig. 3f and g), and pyrite and chalcopyrite occur as disseminations in the groundmass. 


\section{Major and trace element geochemistry}

Whole-rock major element concentrations, from Richards et al. (2001) and this study, are listed in Supplementary Data Table A10 and plotted in Supplementary Data Fig. B1 and Figure 4. Supplementary Data Fig. B1 shows three plots of whole rock oxide and element ratios that have been used to identify alteration in other hydrothermal systems (Large et al., 2001; Urqueta et al., 2009; Warren et al., 2007; Cocker et al., 2015). The rhyolitic porphyry sample (ESC1) is highly silicified and has lost $\mathrm{Na}$ and $\mathrm{Ca}$ during the formation of an alteration assemblage of K-feldspar, chlorite, kaolinite and sericite (Supplementary Data Fig. B1). It was therefore excluded from the major and trace element plots. Samples from the Zaldivar Llamo porphyry (ZAL1 and ZAL4) are moderately altered and have lost K, Na and $\mathrm{Ca}$, which is attributed to the formation of secondary sericite, $\mathrm{K}$-feldspar, biotite, chlorite and kaolinite (Supplementary Data Fig. B1). In contrast, the regional diorite samples show only weak to moderate propylitic alteration; only least-altered samples were studied here.

Variation diagrams for selected whole rock major elements, plotted against $\mathrm{MgO}$, are shown in Figure 4. $\mathrm{K}_{2} \mathrm{O}$ increases in the regional diorites with decreasing $\mathrm{MgO}$ (Fig. 4a), whereas $\mathrm{CaO}, \mathrm{TiO}_{2}$ and total Fe, plotted as $\mathrm{Fe}_{2} \mathrm{O}_{3}$, decrease in all suites (Fig. 4b-d). The porphyry samples fall off the diorite trends for $\mathrm{K}_{2} \mathrm{O}$ and $\mathrm{CaO}$, likely due to alteration.

Whole rock trace-element data are listed in Table 2, and $\mathrm{Ni}, \mathrm{Cr}, \mathrm{Sc}, \mathrm{V}, \mathrm{Zr}, \mathrm{Y}$ and $\mathrm{Cu}$ are plotted against $\mathrm{MgO}$ in Figure 5. The $\mathrm{Ni}, \mathrm{Cr}, \mathrm{Sc}$ and $\mathrm{V}$ content of the samples decreases with decreasing $\mathrm{MgO}$ in all suites (Fig. 5a-d), except for some scatter in the $\mathrm{Ni}$ and $\mathrm{Cr}$ plots. Zirconium initially increases with decreasing MgO, but then falls at c. 2.2 wt.\% MgO (Fig. 5e). $\mathrm{Y}$ and $\mathrm{Yb}$ show no systematic variation with $\mathrm{MgO}$ until the $\mathrm{MgO}$ falls to $2.5 \mathrm{wt} \%$, below which they decrease rapidly to low values in both the low-MgO diorites and the ore-bearing porphyries (Fig. 5f and g). Copper appears to decrease with decreasing $\mathrm{MgO}$ if four low values at about 3.5 wt.\% $\mathrm{MgO}$ are excluded (Fig. 5h), but the correlation coefficient is low. It 
can be said with confidence is that there is no clear evidence of an increase in $\mathrm{Cu}$ with fractionation. The porphyry samples lie on the diorite trends for all elements except for $\mathrm{Cu}$ (Fig. 5h), which lie above the trend, reflecting their mineralized character.

Primitive-mantle normalized trace element and chondrite-normalized rare earth element (REE) patterns for each suite (except ESC1) are plotted in Figure 6. The trace element patterns of the regional diorites are subparallel to each other, with the exception of the three samples with the lowest MgO concentrations (IM151, IM90 and IM119; Fig. 6a and b). Samples IM90 and IM119 have similar trace element patterns to the Escondida porphyry. The patterns all show enrichments in large-ion lithophile elements (LILE; K, Ba, Rb and Sr) and depletions in high field strength elements (HFSE; $\mathrm{Nb}, \mathrm{Ta}, \mathrm{P}$ and $\mathrm{Ce}$ ), especially $\mathrm{Nb}$ and Ta, which are typical features of arc magmas (Pearce and Stern, 2006).

The REE patterns of the regional diorites are subparallel to each other, again with the exception of the three lowest $\mathrm{MgO}$ samples, which have relatively high LREE concentrations in the case of IM151 and low HREE concentrations in the case of IM90 and IM119 (Fig. 6c). Samples IM90 and IM119 have nearly identical REE patterns to the Escondida porphyry (Fig. 6d). The regional diorites show very weak negative Eu anomalies (average $\mathrm{Eu} / \mathrm{Eu}^{*}=0.91$ ), which decrease with decreasing $\mathrm{MgO}$. However, the ore-bearing Escondida porphyry has almost no Eu anomaly (average $\mathrm{Eu} / \mathrm{Eu}^{*}=0.98$ ), whereas the Zaldivar Llamo porphyry has a small negative anomaly (average $\mathrm{Eu} / \mathrm{Eu}^{*}=0.86$ ).

\section{Platinum group element and Re geochemistry}

The PGE and Re data for the analysed samples are listed in Table 3, and Pd, Pt, Ir and Re are plotted against $\mathrm{MgO}$ in Figure 7. The concentrations of $\mathrm{Ru}$ and $\mathrm{Rh}$ in all suites are close to or below the detection limit and are not considered further. The Pd concentrations of the regional 
diorites first decrease slightly, then increase at $~ 3.5 \mathrm{wt} . \% \mathrm{MgO}$, before decreasing again at $\sim 2.5$ wt. $\% \mathrm{MgO}$ to below the detection limit (Fig. 7a). In contrast, the Pd concentrations of the ore-bearing Escondida porphyry range from $\sim 0.2$ to $0.02 \mathrm{ppb}$, but the highest $\mathrm{MgO}$ sample available has only 1.3 wt.\% MgO. Variation in Pt (Fig. 7b) and Ir (Fig. 7c) follow Pd but many of the analyses were close to or below detection, which limits the confidence that can be placed in the trend.

Most duplicate analyses of Pt and Ir for the regional diorites lie outside analytical uncertainty, whereas Pd duplicate analyses for this suite are within the analytical error (Table 3; Fig. 7a) of $<13 \%$, which is taken to be $2 \sigma$ of multiple analyses of TDB- 1 in our laboratory. However, all of the duplicate analyses for Pd, Pt and Ir for the ore-bearing porphyries, except for the Pd duplicates of ESC2, show heterogeneity that lies well outside analytical uncertainty (Table 3; Fig. 7a). The Re concentrations show considerable scatter for all the diorites and porphyries, but the samples from the ore-bearing porphyries have significantly higher Re values than those from the regional diorites (Fig. 7d).

\section{Sr-Nd-Pb isotopes}

Whole rock $\mathrm{Sr}-\mathrm{Nd}-\mathrm{Pb}$ isotopic data are listed in Table 4 and plotted in Figure 8. The age used to calculate the quoted initial values is $38 \mathrm{Ma}$. Both the regional diorites and ore-bearing porphyries have similar $\mathrm{Sr}$ and $\mathrm{Nd}$ isotopic compositions. $\left({ }^{87} \mathrm{Sr} /{ }^{86} \mathrm{Sr}\right)_{\mathrm{i}}$ and $\left({ }^{143} \mathrm{Nd} /{ }^{144} \mathrm{Nd}\right)_{\mathrm{i}}$ ratios of the regional diorites range from 0.704765 to 0.705013 , and 0.512613 to 0.512641 ( $\varepsilon \mathrm{Nd}$ from 0.3 to 1.0 ), respectively (Table 4; Fig. 8a), whereas those of the ore-bearing porphyries range from 0.704926 to 0.705295 , and 0.512583 to 0.512598 ( $\varepsilon N d$ from -0.1 to 0.2 ), respectively (Table 4; Fig. 8a). 
The $\mathrm{Pb}$ isotope data for both suites are also characterised by limited variation, with the following ranges: $\left({ }^{206} \mathrm{~Pb} /{ }^{204} \mathrm{~Pb}\right)_{\mathrm{i}}=18.543$ to $18.569,\left({ }^{207} \mathrm{~Pb} /{ }^{204} \mathrm{~Pb}\right)_{\mathrm{i}}=15.616$ to 15.625 , and $\left({ }^{208} \mathrm{~Pb} /{ }^{204} \mathrm{~Pb}\right)_{\mathrm{i}}=38.516$ to 38.551 for the regional diorites, and $\left({ }^{206} \mathrm{~Pb} /{ }^{204} \mathrm{~Pb}\right)_{\mathrm{i}}=18.586$ to $18.605,\left({ }^{207} \mathrm{~Pb} /{ }^{204} \mathrm{~Pb}\right)_{\mathrm{i}}=15.626$ to 15.630 , and $\left({ }^{208} \mathrm{~Pb} /{ }^{204} \mathrm{~Pb}\right)_{\mathrm{i}}=38.576$ to 38.607 for the orebearing porphyries (Table 4; Fig. $8 \mathrm{~b}$ and c).

\section{Zircon U-Pb geochronology}

The ${ }^{208} \mathrm{~Pb}$ corrected ${ }^{206} \mathrm{~Pb} /{ }^{238} \mathrm{U}$ weighted mean ages for the dated samples (471 analyses) are listed in Table 5 and plotted as cumulative probability plots in Supplementary Data Fig. B2. The data for each analysis are listed in Supplementary Data Table A11. Two samples of the Escondida porphyry gave U-Pb ages of $37.92 \pm 0.44$ and $37.19 \pm 0.44 \mathrm{Ma}$, the Escondida Rhyolitic porphyry an age of $34.97 \pm 0.50 \mathrm{Ma}$, and the Zaldivar Llamo porphyry ages of $38.06 \pm 0.52$ and $37.11 \pm 0.37 \mathrm{Ma}$. The regional diorites yielded ages of $39.62 \pm 0.43$ to 37.07 $\pm 0.63 \mathrm{Ma}$. All uncertainties are quoted at $95 \%$ confidence level. The results are consistent with previous hornblende ${ }^{40} \mathrm{Ar} /{ }^{39} \mathrm{Ar}$ and zircon $\mathrm{U}-\mathrm{Pb}$ dating, which are: Escondida, $37.9 \pm 1.1$ Ma; Escondida Rhyolitic porphyry, 34.7 $\pm 1.7 \mathrm{Ma}$; Zaldivar Llamo porphyry, $37.40 \pm 0.18$ Ma and 38.7 $\pm 1.3 \mathrm{Ma}$; and regional diorites, 38.28 $\pm 0.32 \mathrm{Ma}$ to $36.94 \pm 0.34 \mathrm{Ma}$ (Richards et al., 1999, 2001). The mean square of weighted deviations (MSWD) for all the samples range from 0.78 to 2.2, except for one of the regional diorites IM119, which has a MSWD of 3.3 (Supplementary Data Fig. B2). The high MSWD of IM119 could be due to subtle age zoning within the zircons, which could not be resolved by LA-ICP-MS, or to an underestimation of the propagated errors. If the propagated errors are increased by $\sim 50 \%$, the MSWD falls to 1.5 , but the weighted mean age remains unchanged. 
The ages of the inherited zircons from all the samples range from 37.8 to $405.1 \mathrm{Ma}$, which can be divided into two main groups, each representing $\sim 10 \%$ of the total number of the analysed zircons: Eocene (38-48 Ma) and Paleozoic zircons (mode 275 Ma) (Supplementary Data Fig. B3). The Eocene inherited zircons are interpreted to be antecrysts, whereas the older zircons are interpreted to be xenocrysts, derived from the Paleozoic basement.

\section{Zircon $\mathrm{Ce}^{4+} / \mathrm{Ce}^{3+}$ ratios and Ti thermometry}

$\mathrm{Ce}^{4+} / \mathrm{Ce}^{3+}$ ratios in zircon were calculated using whole-rock and zircon Ce concentrations, following the method described in Ballard et al. (2002). The results are listed in Supplementary Data Table A11, and illustrated in Figure 9. $\mathrm{Ce}^{4+} / \mathrm{Ce}^{3+}$ ratios range from 19 to 2000 for the ore-bearing suites and 17 to 2300 for the regional diorites, with the exception of one zircon from sample IM10, which has a $\mathrm{Ce}^{4+} / \mathrm{Ce}^{3+}$ value of 4 (Supplementary Data Table A11; Fig. 9a).

Titanium-in-zircon temperatures were calculated using the method of Hayden and Watson (2007) and the results are listed in Supplementary Data Table A11, assuming the activities of $\mathrm{SiO}_{2}$ and $\mathrm{TiO}_{2}$ to be 1 and 0.63 , respectively. The activity of $\mathrm{SiO}_{2}$ is based on the occurrence of quartz in all samples, and $\mathrm{a}_{\mathrm{TiO}_{2}}$ is empirically estimated from FeTi oxide pairs following Wark et al. (2007). Although, the $\mathrm{a}_{\mathrm{TiO}_{2}}$ may not always be 0.63 , for most igneous rocks it is $\geq 0.5$ (Hayden and Watson, 2007). The uncertainty in $\mathrm{a}_{\mathrm{TiO}_{2}}$ introduces an error of $30-50{ }^{\circ} \mathrm{C}$ in the calculated temperatures. Furthermore, the titanium-in-zircon geothermometer gives zircon crystallization temperatures rather than liquidus temperatures.

$\mathrm{Ce}^{4+} / \mathrm{Ce}^{3+}$ ratios in zircon have been measured to assess the magma redox state. The plots of $\mathrm{Ce}^{4+} / \mathrm{Ce}^{3+}$ against temperature for both the regional diorites and ore-bearing suites 
show that $\mathrm{Ce}^{4+} / \mathrm{Ce}^{3+}$ ratios generally increase with decreasing temperature, and the data from the evolved diorite (sample IM119, 1.25 wt.\% MgO) overlap those of ore-bearing suites (Fig. $9 b)$.

\section{Zircon O-Hf isotope compositions}

O-Hf isotope values of the zircon autocrysts (sensu Miller et al., 2007) used to date the samples are listed in Supplementary Data Table A11 and plotted in Figure 10. Zircon autocrysts from the ore-bearing porphyries have $\delta^{18} \mathrm{O}$ compositions ranging from mantle-like values (5.3 $\pm 0.6 \%$, 2б; Valley, 2003; Valley et al. 2005) of c. $5 \%$ up to $10.79 \%$ (Fig. 10a).

Zircon autocrysts from two of the regional diorite samples have a limited range of $\delta^{18} \mathrm{O}$ values (IM8 from 5.51 to $6.58 \%$ and IM10 from, 5.42 to $6.02 \%$ ) whereas the range in IM69 is wider, from 4.83 to $13.80 \%$ (Fig. 10a). The analysed inherited zircon grains also show a wide range in $\mathrm{O}$ isotope compositions, from 5.10 to $10.75 \%$ for the ore-bearing porphyries and 5.06 to $7.55 \%$ for one sample (IM10) of the regional diorites (Supplementary Data Fig. B4), with no obvious relationship between the $\mathrm{O}$ isotope compositions and the age of the zircon.

The zircon autocrysts from the ore-bearing porphyries have $\varepsilon \mathrm{Hf}(\mathrm{t})$ values greater than 0 , and most analyses fall within the range of 0.6 to 2.9. The exceptions are ESC1 and ZAL4, each of which include a single zircon with low $\varepsilon \mathrm{Hf}(\mathrm{t})$ values: -5.1 and -1.2 respectively (Fig. $10 b)$. The $\varepsilon \mathrm{Hf}(\mathrm{t})$ values in zircon autocrysts from the regional diorites show similar characteristics, with all but one of the analyses lying between -0.1 and 3.2. The exception is a single zircon from IM10, which gave a $\varepsilon \mathrm{Hf}(\mathrm{t})$ value of -1.3 (Fig. 10b). The inherited grains yielded a wider range of $\varepsilon \mathrm{Hf}(\mathrm{t})$ values from -2.7 to 4.4 , except for one zircon from ESC2 with an age of $405 \mathrm{Ma}$, which gave an $\mathrm{EHf}(\mathrm{t})$ of 10.1 (Supplementary Data Fig. B4). 


\section{DISCUSSION}

\section{Petrogenesis and magmatic evolution of the regional diorites and ore-bearing porphyries}

The ages obtained in this study, for both the regional diorites (39.6 Ma to 37.1 Ma) and orebearing porphyries (38.1 Ma to 35.0 Ma), agree within analytical uncertainty with those reported previously by Richards et al. $(1999,2001)$, but the new dates are more precise (Table 5). The inherited zircons, which range in age from $37.8 \mathrm{Ma}$ to $405.1 \mathrm{Ma}$, are interpreted to be derived from crustal material acquired during magma ascent, and are dominantly zircons from the Paleozoic basement. The age of the molybdenite mineralization in the Escondida deposit has been dated at $36.1 \pm 0.2 \mathrm{Ma}$ to $35.2 \pm 0.2 \mathrm{Ma}$ (Romero et al., 2010), which lies within the age range of the Escondida porphyries.

The age range for the Escondida ore-bearing porphyries and the regional diorites, including the Escondida Rhyolite porphyry, is $c .4 .5 \mathrm{~m}$.y. This is a minimum value because the samples we analysed show a limited $\mathrm{MgO}$ range, and may represent only the final stage of fractionation.

The general coherence of the major elements, trace elements, isotopes and ages for the regional diorites from various locations and the ore-bearing porphyries, suggests that they represent a broadly co-magmatic suite. However, the age range of this suite of $c .4 .5$ m.y. is not consistent with simple solidification of a mid- to upper crustal magma chamber, because a chamber at these crustal levels cannot stay molten for this period of time (Cawthorn and Walraven, 1998). Instead, as observed in many large arc volcanoplutonic systems, this long lifespan suggests repeated replenishment from deeper crustal magma reservoirs, fed from the mantle wedge above a subduction zone (Richards et al., 2001, 2006; Ballard et al, 2001;

Glazner et al., 2004; Grunder et al., 2008; Cocker et al., 2015). 


\section{Major and trace elements}

Most of the major and trace elements from the regional diorites vary smoothly with $\mathrm{MgO}$, which suggests that fractional crystallization dominates element variations. Potassium contents increase with decreasing $\mathrm{MgO}$ in the regional diorites but then decrease in the orebearing porphyries, which indicates that K-feldspar was a late crystallizing phase in this suite (Fig. 4a). Total Fe, plotted as $\mathrm{Fe}_{2} \mathrm{O}_{3}$, decreases with decreasing $\mathrm{MgO}$, accompanied by decreasing $\mathrm{TiO}_{2}$ and $\mathrm{V}$ (Figs. 4c, d and 5d), confirming the petrographic interpretation that magnetite was a liquidus phase, starting at $4.2 \mathrm{wt} \% \mathrm{MgO}$ or earlier. The crystallization of early pyroxene and amphibole also contributed to the decreases in $\mathrm{Fe}_{2} \mathrm{O}_{3}$ and $\mathrm{TiO}_{2}$. The decrease in $\mathrm{Zr}$ at $\sim 2.2 \mathrm{wt} . \% \mathrm{MgO}$ is interpreted to mark the start of zircon crystallization as a liquidus phase (Fig. 5e).

The REE patterns of the regional diorites can be divided into two groups; those with MgO below 2.5 wt.\% (IM151, IM90, IM119) and those with MgO above 2.5 wt\% (Fig. 6). The higher $\mathrm{MgO}$ samples are sub-parallel to each other and show limited variation, especially in the MREE (Sm, Eu and Gd). All of the samples display listric-shaped REE patterns (steep downward slope from LREE to HREE, followed by flattening or slight increase in slope to HREE; Fig. 6) indicative of amphibole fractionation (Hanson, 1980; Lang and Titley, 1998). This characteristic is accentuated in the low-MgO samples (low $\mathrm{Y}$ and $\mathrm{Yb}$ concentrations; Fig. 5f, g), suggesting enhanced amphibole fractionation from more evolved magmas.

\section{Radiogenic isotopes}

The Sr-Nd isotope compositions of the regional diorites and ore-bearing porphyries lie on a mixing curve between primitive intra-oceanic arc magma and the regional Paleozoic basement 
(Fig. 8a). This is consistent with some crustal assimilation during magma ascent. However, the calculated trend line, based on the average composition of primitive arc magmas and the composition of the regional Paleozoic basement, which has an age similar to that of the dominant population of the zircon xenocrysts in the Escondida intrusions, does not pass through the data (see Fig. 8a). Better results are obtained if the isotopic composition of the southern Central Andes basement is used as the contaminant. In either case the required amount of assimilation is $c .10 \%$.

The ore-bearing porphyries have similar $\mathrm{Sr}$ and $\mathrm{Nd}$ isotope compositions to the regional diorites, with the porphyries having slightly lower $\varepsilon N d$ and higher $\left({ }^{87} \mathrm{Sr} /{ }^{86} \mathrm{Sr}\right)_{\mathrm{i}}$ values than the regional diorites (Table 4; Fig. 8a). This combination suggests that the diorites and porphyries originated from similar magmatic sources, with the latter assimilating slightly more crust.

Similar conclusions can be drawn from the $\mathrm{Pb}$ and $\mathrm{Hf}$ isotope results. Both the orebearing porphyries and regional diorites have nearly identical $\mathrm{Pb}$ isotopic compositions. They plot at the edge of the Enriched Mantle II field and within the field of the lower continental crust (Fig. 8b and c). The Hf isotopic compositions of the zircons are also similar, with most having $\varepsilon \mathrm{Hf}(\mathrm{t})$ that lie between 0 to 3.2 (Fig. 10b); exceptions are IM10 and ZAL4, which have zircons with $\varepsilon H f(t)=-1.3$, and $\mathrm{ESC} 1$, which has one grain with $\varepsilon \mathrm{Hf}(\mathrm{t})=-5.1$. The limited range of $\varepsilon \mathrm{Hf}(\mathrm{t})$ values between 1 and 3 is also consistent with incorporation of a small amount of crustal material into a mantle-derived magma. The presence of Paleozoic inherited zircons, with $\varepsilon \operatorname{Hf}(\mathrm{t})$ between -2.7 and 2.4, shows that the incorporated crustal material had a limited isotopic range (Supplementary Data Fig. B4).

The average Hf model age for zircon autocrysts from the regional diorites, using the values of ${ }^{176} \mathrm{Lu} /{ }^{177} \mathrm{Hf}$ and ${ }^{176} \mathrm{Hf} /{ }^{177} \mathrm{Hf}$ for average depleted arc mantle of lizuka et al. (2013), is $839 \pm 116 \mathrm{Ma}(\mathrm{n}=47,2 \sigma$, range 738 to $1029 \mathrm{Ma})$, similar to the average $\mathrm{Nd}$ model age of 
$786 \pm 32 \mathrm{Ma}(\mathrm{n}=5,2 \sigma$, range 765 to $810 \mathrm{Ma}$; Supplementary Data Fig. B5). The average Hf model age for zircon autocrysts from the ore-bearing porphyries of $848 \pm 132 \mathrm{Ma}(\mathrm{n}=66,2 \sigma$, range 760 to $1277 \mathrm{Ma})$ is almost identical to its average $\mathrm{Nd}$ model age of $847 \pm 20 \mathrm{Ma}(\mathrm{n}=4$, $2 \sigma$, range 834 to $858 \mathrm{Ma}$; Supplementary Data Fig. B5) and is similar to the model age of the regional diorites. The Hf model ages of inherited zircons from the regional diorites range between 800 and $1400 \mathrm{Ma}$ (Supplementary Data Fig. B5), whereas model ages for inherited zircons from the ore-bearing porphyries range from 500 to $1300 \mathrm{Ma}$, with most lying between 800 and $1200 \mathrm{Ma}$ (Supplementary Data Fig. B5). The $c .850 \mathrm{Ma}$ Hf model age for zircon autocrysts from both the ore-bearing porphyries and regional diorites is much older than the crystallization age of the rocks, and therefore does not date the timing of the mantle melting event that gave rise to these magmas. Instead, it is likely a hybrid value resulting from mixing between mantle and crustal Hf, with the crustal contribution dominating the model age because of its higher Hf abundances, despite the relatively small estimated bulk contribution (c. 10 wt. \%) suggested by the $\mathrm{Sr}-\mathrm{Nd}$ isotopic data.

\section{Oxygen isotopes}

Most of the analysed autocrystic zircons have $\mathrm{O}$ isotope compositions that lie within the expected range for zircons crystallized from a mantle-derived magma that has undergone only minor crustal contamination (Fig. 10a), consistent with the $c .10 \%$ crustal assimilation based on $\mathrm{Sr}-\mathrm{Nd}$ isotopic compositions. As a consequence, the zircon $\mathrm{O}$ isotope evidence is consistent with the c. $10 \%$ crustal mixing calculated from $\mathrm{Sr}-\mathrm{Nd}$ isotopes. However, the values for zircons from three samples spread to much higher values, in one case (IM69) reaching a maximum of $14 \%$. One possible interpretation is that the affected zircons crystallized during the resorption of high $\delta^{18} \mathrm{O}$ sediments. This should lead to a correlation between high $\delta^{18} \mathrm{O}$ and low $\mathrm{EHf}$ in the zircons, but none was observed. Alternatively, 
metamict grains may have acquired high $\delta^{18} \mathrm{O}$ from meteoric water during alteration.

However, there is no evidence of a correlation between $\delta^{18} \mathrm{O}$ and $\mathrm{U}$ or Th, which might support this hypothesis. Thus, the origin and significance of the high $\delta^{18} \mathrm{O}$ values in some zircons from these samples remains unknown.

\section{Oxidation state of the magma}

An increase in $\mathrm{Ce}^{4+} / \mathrm{Ce}^{3+}$ in zircon has been attributed to an increase in the $\mathrm{fO}_{2}$ of the magma (Ballard et al., 2002) or a decrease in its temperature, or a combination of both (Smythe and Brenan, 2016). Variations in Ti temperature for zircons from a single sample show that they formed over a range of temperatures (Fig. 9b), probably reflecting zircon growth between the liquidus and solidus. If magnetite continues to crystallise over this temperature interval, then the $\mathrm{Fe}^{3+} / \mathrm{Fe}^{2+}$ of the interstitial melt will decrease and its $f \mathrm{O}_{2}$ will fall (e.g. Jenner et al., 2010), which should lower the zircon $\mathrm{Ce}^{4+} / \mathrm{Ce}^{3+}$ ratio.

There is abundant liquidus magnetite in all of the regional diorites, including the most primitive sample analysed. However, the $\mathrm{Ce}^{4+} / \mathrm{Ce}^{3+}$ ratio in zircon crystals increases with falling temperature (Fig. 9b), contrary to the prediction of Jenner et al. (2010), and consistent with increasing oxidation during fractional crystallization and degassing (Ballard et al., 2002; Loucks et al., 2018). Oxygen fugacities, calculated from the equation of Smythe and Brenan (2016), give a range of $\triangle \mathrm{FMQ}$ values from -0.5 to 2.0 for most of the diorites and porphyries (Fig. 11). The water content used in this calculation was 4 wt.\% for all the samples based on the observation of hornblende crystallization. However, the evolved samples, especially the porphyries, may have had higher magmatic water contents ( $\geq 4$ wt.\%; Richards et al., 2001), as water behaves incompatibly during magmatic evolution. Higher water contents result in higher calculated $\triangle F M Q$ (Smythe and Brenan, 2016), so that the magma is expected to be 
moderately oxidized and its $f \mathrm{O}_{2}$ may have increased with fractional crystallization. However, this is inconsistent with the expectation from magnetite crystallization, which predicts a decrease in $f \mathrm{O}_{2}$ due to the higher proportion of $\mathrm{Fe}^{3+}$ to $\mathrm{Fe}^{2+}$ in this mineral $\left(\mathrm{Fe}^{3+}{ }_{2} \mathrm{Fe}^{2+} \mathrm{O}_{4}\right)$. One possible explanation for this apparent contradiction, suggested by Matthews et al. (1999), Richards et al. (2006), and Richards (2015), is that the oxidizing effect of $\mathrm{SO}_{2}$ degassing and/or crystallization of other FeO-rich minerals (such as pyroxene and amphibole) more than counters the reducing effect of magnetite crystallization.

\section{Effect of Pt-alloy nuggets and sulfide mineral grains on PGE concentrations}

The disagreement in duplicate analyses of Pt and Ir but not Pd for the regional diorites (Table

3; Fig. $7 \mathrm{~b}$ and c) suggests that the magma was saturated with, and therefore fractionating, a platinum-group mineral (PGM), probably a Pt-Fe alloy, which can sequester Pt, Ir, Ru, and Rh but not Pd (Fig. 7a; Park et al., 2013b, 2015). No other known phase incorporates this combination of elements.

Triplicate analyses of Pd in whole-rock samples from the ore-bearing Escondida and Zaldivar porphyries, which show that at least one of the analyses for each sample lies well outside the analytical uncertainty of the others (Table 3, Fig. 7a), suggest the inhomogeneous presence of PGE-rich sulfide grains that were introduced by the ore-forming hydrothermal fluids. Mineralization deposited from hydrothermal fluids is known to be very heterogeneous (Cline and Bodnar, 1991; Richards, 2011a).

\section{Sulfide saturation in the regional diorites}

PGE geochemistry has been used to identify sulfide saturation in several evolving magmatic systems (Barnes and Picard, 1993; Barnes et al., 2008, 2015; Keays, 1995; Keays and 
Lightfoot, 2010; Keays et al., 2012; Maier and Barnes, 1999; Maier et al., 2012; Park et al., 2013a, 2013b, 2015; Cocker et al., 2015; Hao et al., 2017; Lowczak et al., 2018). The Pd, Pt and Ir concentrations in the highest $\mathrm{MgO}$ (4.72 wt.\%) samples analysed from the regional diorites are at least 10 times lower than sulfide undersaturated samples from geochemically similar suites at the same MgO content from previous studies (Park et al., 2013a, b, 2015; Cocker et al., 2015; Hao et al., 2017; Lowczak et al., 2018), and decrease with decreasing $\mathrm{MgO}$ (Fig. 12). These observations are interpreted to indicate that sulfide saturation started before the magma evolved to $4.72 \mathrm{wt} . \% \mathrm{MgO}$. The rounded sulfide inclusions (Fig. 3h and i) observed in a regional diorite, with $2.94 \mathrm{wt} . \% \mathrm{MgO}$, indicate that an immiscible sulfide melt continued to precipitate from the silicate melt until its $\mathrm{MgO}$ fell to $<3.0 \mathrm{wt} . \%$.

At c. 3.5 wt. $\% \mathrm{MgO}, \mathrm{Pd}, \mathrm{Pt}$ and Ir increase by at least a factor of 2 with decreasing $\mathrm{MgO}$ (Fig. 7a-c). This suggests the fractionation interval between c. 3.5 and 2.5 wt. $\% \mathrm{MgO}$ was a period of magma replenishment during which one or more new pulses of primitive magma entered the chamber from a deeper source. Mixing of $5 \%$ of a typical primitive arc magma, with 9 wt.\% MgO and 10 ppb Pd (Dale et al., 2012), with an evolved Escondida magma containing $2.5 \mathrm{wt} . \% \mathrm{MgO}$ and $0.02 \mathrm{ppb} \mathrm{Pd}$, can produce the observed increase in $\mathrm{Pd}$ between c. 3.5 and 2.5 wt.\% (see mixing trend in Fig. 7a). The gradual nature of this rise suggests that the chamber received a several small pulses rather than one large pulse, because the latter would have produced a single sharp increase in highly compatible PGE rather than the observed gradual increase.

At c. 2.5 wt. $\% \mathrm{MgO}$, the Pd, Pt and Ir concentrations decrease abruptly to below the detection limit (Fig. 7a-c), which is attributed to continued sulfide precipitation in the absence of new inputs, together with volatile exsolution once the magma became water-saturated. We suggest that precipitation of a small amount of immiscible sulfide melt led to most of the highly chalcophile elements (Au and PGE) being stripped from the magma and locked in a 
cumulus sulfide phase in an underlying parental magma reservoir. However, $\mathrm{Cu}$, with its much greater abundance and relatively low partition coefficient into sulfide melts, was little affected (Fig. 5h), making it available to enter the fluid phase when the magma eventually became volatile-saturated late in its evolution.

The proportion of sulfide melt to precipitate in the regional diorite suite can be calculated from the rate of decrease of $\mathrm{Cu}$ with decreasing $\mathrm{MgO}$ (Fig. 5h). Calculations, using Petrolog (Danyushevsky and Plechov, 2011), suggest that the amount of fractionation required to lower the $\mathrm{MgO}$ from $c .4 .7$ to $1.2 \mathrm{wt} . \%$ is $c .60 \%$. Assuming equilibrium Rayleigh fractionation, and taking the partition coefficient for $\mathrm{Cu}$ to be 1300 (Ripley et al., 2002), the percentage of sulfide melt precipitation required to produce the observed decline in $\mathrm{Cu}$ is $c$. 0.12 wt.\% (as a percentage of the total crystallizing phases). This proportion is similar to other estimates for sulfide-saturated magmas (e.g. Lightfoot and Keays, 2005; Jamais et al., 2008; Park et al., 2013b, 2015; Cocker et al., 2015; Hao et al., 2017).

\section{Implications for ore-forming process}

Whole rock $\mathrm{Sr}-\mathrm{Nd}-\mathrm{Pb}$ and zircon $\mathrm{Hf}-\mathrm{O}$ isotope data show that the regional diorites and orebearing porphyries are derived from isotopically identical mantle sources. This conclusion is supported by the observation that the ore-bearing porphyries lie on the extension of the geochemical and zircon $\mathrm{Ce}^{4+} / \mathrm{Ce}^{3+}$ trend lines defined by the regional diorites as seen in Figures 4, 5, 6 and 9. As a consequence, the regional diorites and ore-bearing porphyries are interpreted to be broadly co-magmatic with the latter being derived by fractional crystallization of the former in a mid-upper crustal batholithic magma chamber (as imaged by Behn et al., 2001). 
It has been suggested that the time interval between sulfide and volatile saturation plays a critical role in determining the fertility of felsic magma systems (Park et al., 2013b, 2015; Cocker et al., 2015; Hao et al., 2017; Lowczak et al., 2018). If ore-associated porphyries were derived by fractional crystallization of the magmatic system that gave rise to the regional diorites, the system reached sulfide saturation early in its evolution, before the magma had fractionated to $4.72 \mathrm{wt} . \% \mathrm{MgO}$, and the percentage of sulfide melt to precipitate is estimated to have been about $0.12 \mathrm{wt} . \%$ of the crystallizing phases. The $\mathrm{MgO}$ content of the melt at the time of ore formation, which is also a time of voluminous fluid release, can be estimated from the composition of the quenched, fine-grained matrix of the associated porphyries, after allowing for $\mathrm{MgO}$ in the phenocrysts (Hao et al., 2017). The phenocrysts in the Escondida porphyry are dominated by low-MgO plagioclase and quartz, so the whole rock $\mathrm{MgO}$ content approximates that of the fine-grained matrix, after allowing for the diluting effect of the phenocrysts. This approach suggests that ore formation from the Escondida magmas occurred at $c .1 .2 \mathrm{wt} . \% \mathrm{MgO}$, but slightly later at $c .0 .45 \mathrm{wt} . \% \mathrm{MgO}$ for Zaldivar (Supplementary Data Table A10). We therefore suggest that, in the Escondida porphyry system, the ore-forming volatile release event occurred well after the onset of sulfide saturation, but the fraction of sulfide to precipitate was low so that it had little effect on the $\mathrm{Cu}$ content of the residual melt, which by extrapolation of the data in Figure 5h, is estimated to lie between $c .35$ to $50 \mathrm{ppm}$ at the time of ore-forming volatile exsolution. This was apparently sufficient to form the Escondida copper deposit (Cline and Bodnar, 1991; Cline, 1995; Richards, 2015). The implication is that it is the size of the magmatic system, rather than the $\mathrm{Cu}$ content of the melt, which led to the formation of the super-giant Escondida copper deposit. The area covered by the regional diorites is ca. 20 x $20 \mathrm{~km}$ (Fig. 2; Richards et al., 2001). If these intrusions are sourced from a single underlying parental magma reservoir that is $1 \mathrm{~km}$ thick, which is the minimum estimation based on the magnetic anomaly 
in the area, and represents the source of the Escondida and Zaldivar Llamo porphyries (Behn et al., 2001), then the volume of this reservoir is $4 \times 10^{11} \mathrm{~m}^{3}\left(400 \mathrm{~km}^{3}\right)$, or $10^{12}$ tonnes. If the $\mathrm{Cu}$ content of the melt is $50 \mathrm{ppm}$, then the contained $\mathrm{Cu}$ is $5 \times 10^{7}$ tonnes in total, which compares with $6 \times 10^{7}$ tonnes of contained $\mathrm{Cu}$ in the combined reserve and resource at Escondida and Zaldivar. If volatile saturation occurred towards the end of fractionation, after $80 \%$ to $90 \%$ fractionation, the mass of magma would need to be increased by a factor of 5 to 10 , and by even more if $\mathrm{Cu}$ extraction by the hydrothermal fluid and precipitation is not $100 \%$ efficient. A volume of $400 \mathrm{~km}^{3}$ is therefore the minimum size of the postulated magma reservoir that gave rise to the Escondida and Zaldivar porphyries, compatible with our hypothesis that the ore-bearing porphyries and regional diorites are part of a single large magmatic system.

\section{A model for chalcophile element fractionation}

If the percentage of sulfide melt precipitation $(0.12 \mathrm{wt} . \%$ of the total crystallizing phases, estimated from the change in the $\mathrm{Cu}$ concentration with decreasing $\mathrm{MgO}$ ) is used to calculate the rate of decrease in $\mathrm{Pd}$ with decreasing $\mathrm{MgO}, \mathrm{Pd}$ concentrations will fall to below the detection limit with less than 5\% fractional crystallization if the partition coefficient for Pd between immiscible sulfide and silicate melts is assumed to be $10^{5}$ (Mungall and Brenan, 2014). The rate of decline decreases if monosulfide solid solution (MSS) replaces sulfide melt as the precipitating S phase at $<3.0 \mathrm{wt} . \% \mathrm{MgO}$, because the partition coefficient of Pd into MSS is $c .10$ times lower than it is into a sulfide melt (Liu and Brenan, 2015). Nevertheless, the bulk partition coefficient for $\mathrm{Pd}$ is still $>10$, so it will continue to decline at a significant rate. This expected rapid depletion in Pd is not observed (Fig. 7a), which suggests the immiscible sulfide melt may not have reached equilibrium with the full volume of silicate melt. Campbell and Naldrett (1979) proposed that R, the mass ratio of silicate to sulfide melt, 
can influence the apparent partition coefficient (D') for the partitioning of chalcophile elements between an immiscible sulfide melt and silicate melt when the true $\mathrm{D}$ for the element is $>\mathrm{R}$. $\mathrm{R}$ can be reduced if precipitation of the immiscible sulfide melt is rapid (Keays and Campbell, 1981; Mungall and Brenan, 2014), or if the sulfide melt precipitates only from the lowermost convecting layer in a compositionally zoned magma chamber. Either of these processes can restrict the mass of silicate melt a precipitating sulfide melt can extract chalcophile elements from. $\mathrm{R}$ in this case is a dynamic $\mathrm{R}$, the ratio of the mass of silicate melt that a sulfide droplet of given mass can reach equilibrium with before it is buried in the crystal pile (Hao et al., 2017). The relationship among D, D' and R' during non-equilibrium sulfide precipitation is:

$D^{\prime}=D\left(R^{\prime}+1\right) /\left(R^{\prime}+D\right)$

If $\mathrm{R}^{\prime}>>\mathrm{D}, \mathrm{D}^{\prime} \sim \mathrm{D}$, but if $\mathrm{R}^{\prime}<<\mathrm{D}$, then $\mathrm{D}^{\prime} \sim \mathrm{R}^{\prime}$ and R' plays a critical role in determining the rate of decrease in highly chalcophile elements (Au and PGE) following sulfide saturation. For example if $\mathrm{R}^{\prime}=5000, \mathrm{R}^{\prime}$ has a significant effect on D' for Pd and $\mathrm{Au}$, with Pd being more affected than Au. Copper, with its lower partition coefficient, is little affected.

The influence of sulfide saturation on chalcophile element geochemistry can be modelled using published partition coefficients for $\mathrm{Cu}, \mathrm{Au}$ and $\mathrm{Pd}$ between sulfide and silicate melts, and the previous estimated fraction of immiscible sulfide to precipitate from the silicate melt, provided the amount of magma fractionation prior to sulfide saturation is known (Cocker et al., 2015; Hao et al., 2017; Lowczak et al., 2018). The amount of fractionation was estimated using Petrolog (Danyushevsky and Plechov, 2011), assuming the magma fractionated from an initial value of $9.0 \mathrm{wt} . \% \mathrm{MgO}$ and evolved to $c .6 .0 \mathrm{wt} . \% \mathrm{MgO}$ before the onset on sulfide saturation. The calculated amount of fractionation is $c .45 \%$, but this should be regarded as indicative only, because the primitive magma may have had a higher $\mathrm{MgO}$ content than 9 wt.\%, sulfide saturation could have started before 6 wt.\% $\mathrm{MgO}$, and 
Petrolog cannot model hornblende fractionation but substitutes augite instead as the principal ferromagnesium phase. The onset of cumulus sulfide precipitation has been assumed to be gradational over 10\% fractionation, as described in Keays and Tegner (2016) for the

Skaergaard intrusion of East Greenland. The assumed R' values are R' >> D Pd (Fig. 13a) and $\mathrm{R}^{\prime}=5,000$ (Fig. 13b). The results show that the concentrations of $\mathrm{Cu}, \mathrm{Au}$ and $\mathrm{Pd}$ in the magma increase until sulfide saturation occurs (Fig. 13). Once sulfide saturation is reached the $\mathrm{Pd}, \mathrm{Au}$ and $\mathrm{Cu}$ content of the melt fall, with the rate of decline being controlled by their apparent partition coefficients (D'), that is $\mathrm{Pd}>\mathrm{Au}>\mathrm{Cu}$. Detailed modeling shows that amount of $\mathrm{Pd}, \mathrm{Au}$ and $\mathrm{Cu}$, inferred to have been introduced by new input of primitive magma at $c .3 .5 \mathrm{wt} . \% \mathrm{MgO}$, was too small to affect this conclusion.

It is apparent from Figure 13 that, by the time of voluminous fluid release from the batholithic magma chamber, early sulfide saturation would have resulted in rapid depletion of Au and Pd for R' >> D Pd (Fig. 13a), but only moderate depletion of $\mathrm{Au}$ and $\mathrm{Pd}$ for $\mathrm{R}^{\prime}=5,000$ (Fig. 13b). As a consequence, some Pd and Au would remain in the melt at volatile saturation, enough to allow a small amount of $\mathrm{Au}$ and $\mathrm{Pd}$ to enter the ore fluid, which may explain why the Escondida ore contains detectable Pd and has a gold credit. The Zaldivar Llamo porphyry system, on the other hand, reached ore-forming volatile saturation later (at c. $0.45 \mathrm{wt} . \% \mathrm{MgO}$ for the ore-bearing porphyry), which can be explained by a longer fractionation interval between sulfide and volatile saturation, resulting in the ore containing little Au.

\section{An empirical method of distinguishing ore bearing from barren felsic systems}

This study suggests that three factors are important in determining magma fertility: (i) the timing of sulfide saturation, (ii) the amount of sulfide to precipitate, and (iii) the timing of voluminous fluid release. $\mathrm{Pd} / \mathrm{MgO}$ is a measure of the first two factors and, the $\mathrm{Y}$ content of 
the melt a measure of the potential for ore-forming fluid release. $\mathrm{Pd} / \mathrm{MgO}$ is used in preference to $\mathrm{Pd}$ to correct the variation of Pd content resulting from fractional crystallization (Park et al., 2018), and low Y, which is controlled by amphibole fractionation, is a measure of the water content of the melt. Figure 14 shows a plot of $\mathrm{Pd} / \mathrm{MgO}$ against $\mathrm{Y}$ for several orebearing and barren systems with $\mathrm{MgO}<2.5$ wt.\%. Following Park et al. (2018) only low$\mathrm{MgO}$ samples are plotted because most ore-bearing porphyries have $\mathrm{MgO}<2.5 \mathrm{wt} . \%$. The plot successfully divides ore bearing from barren suites, and $\mathrm{Cu}$ from $\mathrm{Au}-\mathrm{Cu}$ porphyry systems. If $\mathrm{Pd}$ in the ore-associated porphyries is introduced by the ore-forming hydrothermal fluid, the success of the diagram in discriminating $\mathrm{Cu}$-only systems from barren suites may be based on secondary rather than primary processes. Nevertheless, the empirical separation of these systems remains.

\section{CONCLUSIONS}

The U-Pb zircon ages for the regional dioritic intrusions and ore-bearing porphyries in the Escondida district overlap. Furthermore, the trace element and isotopic composition of the regional diorites and ore-bearing porphyries are virtually identical, which suggests that they are co-magmatic and originated from the same mantle-derived magmatic source, with minor assimilation of the host Paleozoic crust $(c .10 \%)$ en route to emplacement in the upper crust. The magmatic system reached sulfide saturation before the magma fractionated to $4.7 \mathrm{wt} . \%$ $\mathrm{MgO}$, and well before ore formation. Early sulfide saturation sequestered the highly chalcophile elements (Au and PGE) into cumulus sulfides in an underlying magma chamber. However, the proportion of immiscible sulfide precipitation was low (c. $0.12 \mathrm{wt} . \%)$, so that it had little effect on $\mathrm{Cu}$. As a consequence, enough $\mathrm{Cu}$ remained in the melt (35 to $50 \mathrm{ppm}$ ) by the time it reached voluminous volatile saturation to allow the formation of a super-giant $\mathrm{Cu}$ 
deposit. Mass balance calculations show that the mass of the magma chamber that gave rise to the Escondida and Zaldivar Llamo deposits is at least $10^{12}$ tonnes, with a volume of $>400$ $\mathrm{km}^{3}$, which is consistent with the area covered by the regional dioritic intrusions, which are interpreted to sample earlier stages in the evolution of the Escondida magmatic system. The low Au content of the Escondida porphyry ore is attributed to early sulfide saturation, which sequestered most of the Au. The timing of sulfide saturation, the amount of sulfide to precipitate, and the water content of the melt are important factors in determining ore formation. Therefore plots, of $\mathrm{Pd} / \mathrm{MgO}$, a measure of the timing and the fraction of sulfide precipitation, against $\mathrm{Y}$, a measure of water content, may distinguish ore-bearing from barren suites and, in the case of ore-bearing suites, porphyry $\mathrm{Cu}$ from porphyry $\mathrm{Au}-\mathrm{Cu}$ systems.

\section{ACKNOWLEDGEMENTS}

This work was supported by the Australian Research Council [DP170103140]. We would like to thank Prof. Ian Williams and Trevor Ireland, Dr Bin Fu, Peter Holden, Janaina Avila and Mr Les Kinsley for assistance with zircon O and Hf isotope analyses. Samples used in this study were originally collected by Richards, with support from Rio Tinto, Outokumpu, and a grant from the Natural Environment Research Council (UK). We also would like to thank Dr Tutomu Ota, Ryoji Tanaka and all the other members of the Pheasant Memorial Laboratory for technical help and constructive discussions for $\mathrm{Sr}-\mathrm{Nd}-\mathrm{Pb}$ isotope analysis. Hongda Hao acknowledges the China Scholarship Council (CSC) for supporting his study at ANU, and the Institute for Planetary Materials, Okayama University, for supporting his stay in Misasa. We thank Andreas Audétat, Frances Jenner and an anonymous reviewer for their helpful and constructive comments, and Georg Zellmer for his efficient editorial handling. 


\section{REFERENCES}

Allègre, C. J., Lewin, E. \& Dupré, B. (1988). A coherent crust-mantle model for the uranium-thoriumlead isotopic system. Chemical Geology 70(3), 211-234.

Allen, C. M., \& Campbell, I. H. (2012). Identification and elimination of a matrix-induced systematic error in LA-ICP-MS ${ }^{206} \mathrm{~Pb} /{ }^{238} \mathrm{U}$ dating of zircon. Chemical Geology 332, 157-165.

Andersen, J. C., Rasmussen, H., Nielsen, T. F. \& Ronsbo, J. G. (1998). The Triple Group and the Platinova gold and palladium reefs in the Skaergaard Intrusion; stratigraphic and petrographic relations. Economic Geology 93(4), 488-509.

Audétat, A. \& Simon, A. C. (2012). Magmatic controls on porphyry copper genesis. Geology and genesis of major copper deposits and districts of the world-A tribute to Richard H. Sillitoe, 553-572.

Ballard, J. R., Palin, J. M., Williams, I. S., Campbell, I. H. \& Faunes, A. (2001). Two ages of porphyry intrusion resolved for the super-giant Chuquicamata copper deposit of northern Chile by ELA-ICP-MS and SHRIMP. Geology 29(5), 383-386.

Ballard, J. R., Palin, M. J. \& Campbell, I. H. (2002). Relative oxidation states of magmas inferred from $\mathrm{Ce}$ (IV)/Ce (III) in zircon: application to porphyry copper deposits of northern Chile. Contributions to Mineralogy and Petrology 144(3), 347-364.

Barnes, S. J. \& Picard, C. P. (1993). The behaviour of platinum-group elements during partial melting, crystal fractionation, and sulphide segregation: an example from the Cape Smith Fold Belt, northern Quebec. Geochimica et Cosmochimica Acta 57(1), 79-87.

Barnes, S. J., Prichard, H. M., Cox, R. A., Fisher, P. C. \& Godel, B. (2008). The location of the chalcophile and siderophile elements in platinum-group element ore deposits (a textural, microbeam and whole rock geochemical study): Implications for the formation of the deposits. Chemical Geology 248(3-4), 295-317.

Barnes, S. J., Mungall, J. E. \& Maier, W. D. (2015). Platinum group elements in mantle melts and mantle samples. Lithos 232, 395-417.

Behn, G., Camus, F., Carrasco, P. \& Ware, H. (2001). Aeromagnetic signature of porphyry copper systems in northern Chile and its geologic implications. Economic Geology, 96(2), 239-248.Black, L. P., Kamo, S. L., Allen, C. M., Davis, D. W., Aleinikoff, J. N., Valley, J. W., Mundil, R., Campbell, I. H., Korsch, R. J., Williams, I. S. \& Foudoulis, C. (2004). Improved ${ }^{206} \mathrm{~Pb} /{ }^{238} \mathrm{U}$ microprobe geochronology by the monitoring of a trace-element-related matrix effect; SHRIMP, ID-TIMS, ELA-ICP-MS and oxygen isotope documentation for a series of zircon standards. Chemical Geology 205(1-2), 115-140.

Burnham, C.W. (1979). Magmas and hydrothermal fluids, in Barnes, H.L., ed. Geochemistry of hydrothermal ore deposits, 2nd edition: New York, John Wiley and Sons, 71-136.

Campbell, I. H. \& Naldrett, A. J. (1979). The influence of silicate: sulfide ratios on the geochemistry of magmatic sulfides. Economic Geology 74(6), 1503-1506.

Campbell, I. H., Ballard, J. R., Palin, J. M., Allen, C. \& Faunes, A. (2006). U-Pb zircon geochronology of granitic rocks from the Chuquicamata-El Abra porphyry copper belt of northern Chile: excimer laser ablation ICP-MS analysis. Economic Geology 101(7), 1327-1344.

Candela, P.A. (1992) Controls on ore metal ratios in granite-related ore systems: An experimental and computational approach. Earth and Environmental Science Transactions of the Royal Society of Edinburgh 83(1-2), 317-326.

Candela, P.A. \& Piccoli, P.M. (2005) Magmatic processes in the development of porphyry-type ore systems. Economic Geology 100, 25-37. 
Cawthorn, R. G. \& Walraven, F. (1998). Emplacement and crystallization time for the Bushveld Complex. Journal of Petrology 39(9), 1669-1687.

Chou, I. M. (1978). Calibration of oxygen bufrers at elevated P and T using the hydrogen fugacity sensor. American Mineralogist 63, 690-703.

Cline, J. S. \& Bodnar, R. J. (1991) Can economic porphyry copper mineralization be generated by a typical calc-alkaline melt? Journal of Geophysical Research 96(B5), 8113-8126.

Cline, J. S. (1995). Genesis of porphyry copper deposits: the behavior of water, chloride, and copper in crystallizing melts. Arizona Geological Society Digest 20, 69-82.

Cocker, H. A., Valente, D. L., Park, J. W. \& Campbell, I. H. (2015). Using platinum group elements to identify sulfide saturation in a porphyry $\mathrm{Cu}$ system: the El Abra porphyry Cu deposit, Northern Chile. Journal of Petrology 56(12), 2491-2514.

Compston, W., Williams, I. S. \& Meyer, C. (1984). U-Pb geochronology of zircons from lunar breccia 73217 using a sensitive high mass-resolution ion microprobe. Journal of Geophysical Research: Solid Earth 89(S02).

Cooke, D. R., Hollings, P. \& Walshe, J. L. (2005). Giant porphyry deposits: characteristics, distribution, and tectonic controls. Economic geology 100(5), 801-818.

Cornejo, P., Tosdal, R. M., Mpodozis, C., Tomlinson, A. J., Rivera, O. \& Fanning, C. M. (1997). El

Salvador, Chile porphyry copper deposit revisited: geologic and geochronologic framework. International Geology Review 39(1), 22-54.

Cumming, G. L. \& Richards, J. R. (1975). Ore lead isotope ratios in a continuously changing Earth. Earth and Planetary Science Letters 28(2), 155-171.

Dale, C. W., Macpherson, C. G., Person, D. G., Hammond, S. J. \& Arculus, R. J. (2012). Inter-element fractionation of highly siderophile elements in the Tonga Arc due to flux melting of a depleted source. Geochimica et Cosmochimica Acta 89, 202-225.

Danyushevsky, L. V. \& Plechov, P. (2011). Petrolog3: Integrated software for modeling crystallization processes. Geochemistry, Geophysics, Geosystems 12(7).

Dilles, J. H., Kent, A. J., Wooden, J. L., Tosdal, R. M., Koleszar, A., Lee, R. G. \& Farmer, L. P. (2015). Zircon compositional evidence for sulfur-degassing from ore-forming arc magmas. Economic Geology, 110(1), 241-251.

Eggins, S. M., Grün, R., McCulloch, M. T., Pike, A. W., Chappell, J., Kinsley, L., Mortimer, G., Shelley, M., Murray-Wallace, C. V., Spötl, C. \& Taylor, L. (2005). In situ U-series dating by laser-ablation multicollector ICPMS: new prospects for Quaternary geochronology. Quaternary Science Reviews 24(2324), 2523-2538.

Glazner, A.F., Bartley, J.M., Coleman, D.S., Gray, W. \& Taylor, R.Z. (2004). Are plutons assembled over millions of years by amalgamation from small magma chambers? GSA Today 14, 4-11.

Goldstein, S. L., O'nions, R. K. \& Hamilton, P. J. (1984). A Sm-Nd isotopic study of atmospheric dusts and particulates from major river systems. Earth and planetary Science letters 70(2), 221-236.

Grunder, A.L., Klemetti, E.W., Feeley, T.C. \& McKee, C.M., 2008, Eleven million years of arc volcanism at the Aucanquilcha Volcanic Cluster, northern Chilean Andes: implications for the life span and emplacement of plutons, Royal Society of Edinburgh, Transactions: Earth Sciences 97, 415-436.

Hamlyn, P. R., Keays, R. R., Cameron, W. E., Crawford, A. J. \& Waldron, H. M. (1985). Precious metals in magnesian low-Ti lavas: implications for metallogenesis and sulfur saturation in primary magmas. Geochimica et Cosmochimica Acta 49(8), 1797-1811.

Hanson, G. N. (1980). Rare earth elements in petrogenetic studies of igneous systems. Annual Review of Earth and Planetary Sciences, 8(1), 371-406. 
Hao, H., Campbell, I. H., Park, J. W. \& Cooke, D. R. (2017). Platinum-group element geochemistry used to determine $\mathrm{Cu}$ and Au fertility in the Northparkes igneous suites, New South Wales,

Australia. Geochimica et Cosmochimica Acta 216, 372-392.

Hart, S. R. (1984). A large-scale isotope anomaly in the Southern Hemisphere mantle. Nature, 309(5971), 753.

Hawkesworth, C. J., Gallagher, K., Hergt, J. M. \& McDermott, F. (1993). Mantle and slab contributions in arc magmas. Annual Review of Earth and Planetary Sciences 21(1), 175-204.

Hayden, L. A. \& Watson, E. B. (2007). Rutile saturation in hydrous siliceous melts and its bearing on Ti-thermometry of quartz and zircon. Earth and Planetary Science Letters 258(3-4), 561-568.

Hervé, M., Sillitoe, R.H., Wong, C., Fernández, P., Crignola, F., Ipinza, M. \& Urzúa, F. (2012). Geologic overview of the Escondida porphyry copper district, northern Chile. Society of Economic Geologists, Special Publication 16, 55-78.

Hiess, J., Bennett, V. C., Nutman, A. P. \& Williams, I. S. (2009). In situ U-Pb, O and Hf isotopic compositions of zircon and olivine from Eoarchaean rocks, West Greenland: New insights to making old crust. Geochimica et Cosmochimica Acta 73(15), 4489-4516.

Huebner, J. S. \& Sato, M. (1970). The oxygen fugacity-temperature relationships of manganese and nickel oxide buffers. American Mineralogist 55, 934-952.

Ickert, R. B., Hiess, J., Williams, I. S., Holden, P., Ireland, T. R., Lanc, P., Schram N., Foster F. F. \& Clement, S. W. (2008). Determining high precision, in situ, oxygen isotope ratios with a SHRIMP II: analyses of MPI-DING silicate-glass reference materials and zircon from contrasting granites. Chemical Geology 257(1-2), 114-128.

lizuka, T., Campbell, I. H., Allen, C. M., Gill, J. B., Maruyama, S. \& Makoka, F. (2013). Evolution of the African continental crust as recorded by $\mathrm{U}-\mathrm{Pb}, \mathrm{Lu}-\mathrm{Hf}$ and $\mathrm{O}$ isotopes in detrital zircons from modern rivers. Geochimica et Cosmochimica Acta 107, 96-120.

Ireland, T. R. \& Williams, I. S. (2003). Considerations in zircon geochronology by SIMS. Reviews in mineralogy and geochemistry 53(1), 215-241.

Jamais, M., Lassiter, J. C. \& Brügmann, G. (2008). PGE and Os-isotopic variations in lavas from Kohala Volcano, Hawaii: constraints on PGE behavior and melt/crust interaction. Chemical

Geology 250(1), 16-28.

Jenner, F. E., O'Neill, H. S. C., Arculus, R. J. \& Mavrogenes, J. A. (2010). The magnetite crisis in the evolution of arc-related magmas and the initial concentration of $\mathrm{Au}, \mathrm{Ag}$ and $\mathrm{Cu}$. Journal of

Petrology 51(12), 2445-2464.

Jochum, K. P., Weis, U., Stoll, B., Kuzmin, D., Yang, Q., Raczek, I., Jacob, D. E., Stracke, A., Birbaum, K. \& Frick, D. A. (2011). Determination of reference values for NIST SRM 610-617 glasses following ISO guidelines. Geostandards and Geoanalytical Research 35, 397-429.

Jugo, P. J. (2009). Sulfur content at sulfide saturation in oxidized magmas. Geology, 37(5), 415-418.

Keays, R. R. (1995). The role of komatiitic and picritic magmatism and S-saturation in the formation of ore deposits. Lithos 34(1-3), 1-18.

Keays, R. R. \& Lightfoot, P. C. (2010). Crustal sulfur is required to form magmatic Ni-Cu sulfide deposits: evidence from chalcophile element signatures of Siberian and Deccan Trap basalts. Mineralium Deposita 45(3), 241-257.

Keays, R. R. \& Tegner, C. (2015). Magma chamber processes in the formation of the low-sulphide magmatic Au-PGE mineralization of the Platinova Reef in the Skaergaard Intrusion, East

Greenland. Journal of Petrology 56(12), 2319-2340. 
Keays, R. R., Lightfoot, P. C. \& Hamlyn, P. R. (2012). Sulfide saturation history of the Stillwater Complex, Montana: chemostratigraphic variation in platinum group elements. Mineralium Deposita 47(1-2), 151-173.

Kuritani, T. \& Nakamura, E. (2002). Precise isotope analysis of nanogram-level Pb for natural rock samples without use of double spikes. Chemical Geology 186(1-2), 31-43.

Lang, J. R. \& Titley, S. R. (1998). Isotopic and geochemical characteristics of Laramide magmatic systems in Arizona and implications for the genesis of porphyry copper deposits. Economic Geology, 93(2), 138-170.

Large, R. R., Gemmell, J. B., Paulick, H. \& Huston, D. L. (2001). The alteration box plot: A simple approach to understanding the relationship between alteration mineralogy and lithogeochemistry associated with volcanic-hosted massive sulfide deposits. Economic geology 96(5), 957-971.

Li, Y. \& Audétat, A. (2015). Effects of temperature, silicate melt composition, and oxygen fugacity on the partitioning of $\mathrm{V}, \mathrm{Mn}, \mathrm{Co}, \mathrm{Ni}, \mathrm{Cu}, \mathrm{Zn}, \mathrm{As}, \mathrm{Mo}, \mathrm{Ag}, \mathrm{Sn}, \mathrm{Sb}, \mathrm{W}, \mathrm{Au}, \mathrm{Pb}$, and Bi between sulfide phases and silicate melt. Geochimica et Cosmochimica Acta 162, 25-45.

Lightfoot, P. C. \& Keays, R. R. (2005). Siderophile and chalcophile metal variations in flood basalts from the Siberian trap, Noril'sk region: Implications for the origin of the Ni-Cu-PGE sulfide ores. Economic Geology 100(3), 439-462.

Liu, Y. \& Brenan, J. (2015). Partitioning of Platinum-Group elements (PGE) and chalcogens (Se, As, $\mathrm{Te}, \mathrm{Sb}, \mathrm{Bi}$ ) between monosulfide-solid solution (MSS), intermediate solid solution (ISS) and sulfide liquid at controlled $\mathrm{fO}_{2}-\mathrm{fS}_{2}$ conditions. Geochimica et Cosmochimica Acta 159, 139-161.

Loucks, R. R., Fiorentini, M. L. \& Rohrlach, B. D. (2018). Divergent $\mathrm{T}-\mathrm{fO}_{2}$ paths during crystallisation of $\mathrm{H}_{2} \mathrm{O}$-rich and $\mathrm{H}_{2} \mathrm{O}$-poor magmas as recorded by $\mathrm{Ce}$ and $\mathrm{U}$ in zircon, with implications for TitaniQ and TitaniZ geothermometry. Contributions to Mineralogy and Petrology, 173(12), 104.

Lowczak, J. N., Campbell, I. H., Cocker, H., Park, J. W. \& Cooke, D. R. (2018). Platinum-group element geochemistry of the Forest Reef Volcanics, southeastern Australia: Implications for porphyry Au-Cu mineralisation. Geochimica et Cosmochimica Acta 220, 385-406.

Lucassen, F., Franz, G., Thirlwall, M. F. \& Mezger, K. (1999). Crustal recycling of metamorphic basement: Late Palaeozoic granitoids of northern Chile ( 22 S). Implications for the composition of the Andean Crust. Journal of Petrology 40(10), 1527-1551.

Lucassen, F., Becchio, R., Harmon, R., Kasemann, S., Franz, G., Trumbull, R., Wilke, H. G., Romer, R. L. \& Dulski, P. (2001). Composition and density model of the continental crust at an active continental margin—the Central Andes between $21^{\circ}$ and $27^{\circ}$ S. Tectonophysics 341(1-4), 195-223.

Lucassen, F., Trumbull, R., Franz, G., Creixell, C., Vásquez, P., Romer, R. L. \& Figueroa, O. (2004). Distinguishing crustal recycling and juvenile additions at active continental margins: the Paleozoic to recent compositional evolution of the Chilean Pacific margin (36-41 S). Journal of South American Earth Sciences 17(2), 103-119.

Ludwig, K. R. (2012). Isoplot 3.75. A Geochronological toolkit for Microsoft Excel. Berkeley Geochronology Center Special Publication 5.

Maier, W. D. \& Barnes, S. J. (1999). Platinum-group elements in silicate rocks of the lower, critical and main zones at Union Section, western Bushveld Complex. Journal of Petrology 40(11), 1647-1671.

Maier, W. D., Peltonen, P., McDonald, I., Barnes, S. J., Barnes, S. J., Hatton, C. \& Viljoen, F. (2012). The concentration of platinum-group elements and gold in southern African and Karelian kimberlitehosted mantle xenoliths: Implications for the noble metal content of the Earth's mantle. Chemical Geology 302, 119-135. 
Masterman, G. J., Cooke, D. R., Berry, R. F., Walshe, J. L., Lee, A. W. \& Clark, A. H. (2005). Fluid chemistry, structural setting, and emplacement history of the Rosario Cu-Mo porphyry and Cu-Ag-Au epithermal veins, Collahuasi district, northern Chile. Economic Geology 100(5), 835-862.

Matthews, S.J., Moncrieff, D.H.S. \& Carroll, M.R. (1999). Empirical calibration of the sulphur valence oxygen barometer from natural and experimental glasses: method and applications. Mineralogical Magazine 63, 421- 431.

McDonough, W. F. \& Sun, S. S. (1995). The composition of the Earth. Chemical geology 120(3-4), 223-253.

Mclnnes, B. I., McBride, J. S., Evans, N. J., Lambert, D. D. \& Andrew, A. S. (1999). Osmium isotope constraints on ore metal recycling in subduction zones. Science 286(5439), 512-516.

Meisel, T., Fellner, N. \& Moser, J. (2003). A simple procedure for the determination of platinum group elements and rhenium ( $\mathrm{Ru}, \mathrm{Rh}, \mathrm{Pd}, \mathrm{Re}, \mathrm{Os}$, Ir and Pt) using ID-ICP-MS with an inexpensive on-line matrix separation in geological and environmental materials. Journal of Analytical Atomic Spectrometry 18(7), 720-726.

Meisel, T. \& Moser, J. (2004). Platinum-Group Element and Rhenium Concentrations in Low Abundance Reference Materials. Geostandards and Geoanalytical Research 28(2), 233-250.

Miller, J. S., Matzel, J. E., Miller, C. F., Burgess, S. D. \& Miller, R. B. (2007). Zircon growth and recycling during the assembly of large, composite arc plutons. Journal of Volcanology and Geothermal Research 167(1-4), 282-299.

Mitchell, R. H. \& Keays, R. R. (1981). Abundance and distribution of gold, palladium and iridium in some spinel and garnet Iherzolites: implications for the nature and origin of precious metal-rich intergranular components in the upper mantle. Geochimica et Cosmochimica Acta 45(12), 2425-2442.

Morris, P. A., Scheib, A., J. \& de Souza Kovacs, N. (2015) Regolith geochemistry of the Dambimangari area, west Kimberley. Geological Survey of Western Australian Record 2015/9, 142.

Mungall, J. E. (2002). Roasting the mantle: Slab melting and the genesis of major $\mathrm{Au}$ and $\mathrm{Au}$-rich $\mathrm{Cu}$ deposits. Geology 30(10), 915-918.

Nakamura, E., Makishima, A., Moriguti, T., Kobayasgi, K., Sakaguchi, C., Yokoyama, T., Tanaka, R., Kuritani, T. \& Takei, H. (2003). Comprehensive geochemical analyses of small amounts $(<100 \mathrm{mg})$ of extraterrestrial samples for the analytical competition related to the sample return mission MUSES-C. The Institute of Space and Astronautical Science report SP 16, 49.

O'Neill, H. S. C. (1987). Quartz-fayalite-iron and quartz-fayalite-magnetite equilibria and the free energy of formation of fayalite $\left(\mathrm{Fe}_{2} \mathrm{SiO}_{4}\right)$ and magnetite $\left(\mathrm{Fe}_{3} \mathrm{O}_{4}\right)$. American Mineralogist 72, 67-75.

O'Neill, H. S. C. \& Mavrogenes, J. A. (2002). The sulfide capacity and the sulfur content at sulfide saturation of silicate melts at $1400 \mathrm{C}$ and 1 bar. Journal of Petrology, 43(6), 1049-1087.

Ossandón C, G., Fréraut C, R., Gustafson, L. B., Lindsay, D. D. \& Zentilli, M. (2001). Geology of the Chuquicamata mine: A progress report. Economic Geology 96(2), 249-270.

Padilla Garza, R. A., Titley, S. R. \& Pimentel B, F. (2001). Geology of the Escondida porphyry copper deposit, Antofagasta region, Chile. Economic Geology 96(2), 307-324.

Park, J. W., Campbell, I. H. \& Eggins, S. M. (2012a). Enrichment of Rh, Ru, Ir and Os in Cr spinels from oxidized magmas: evidence from the Ambae volcano, Vanuatu. Geochimica et Cosmochimica Acta 78, 28-50.

Park, J. W., Hu, Z., Gao, S., Campbell, I. H. \& Gong, H. (2012b). Platinum group element abundances in the upper continental crust revisited-New constraints from analyses of Chinese loess. Geochimica et Cosmochimica Acta 93, 63-76. 
Park, J. W., Campbell, I. H., Ickert, R. B. \& Allen, C. M. (2013a). Chalcophile element geochemistry of the Boggy Plain zoned pluton, southeastern Australia: a S-saturated barren compositionally diverse magmatic system. Contributions to Mineralogy and Petrology 165(2), 217-236.

Park, J. W., Campbell, I. H. \& Arculus, R. J. (2013b). Platinum-alloy and sulfur saturation in an arcrelated basalt to rhyolite suite: Evidence from the Pual Ridge lavas, the Eastern Manus Basin. Geochimica et Cosmochimica Acta 101, 76-95.

Park, J. W., Campbell, I. H., Kim, J. \& Moon, J. W. (2015). The role of late sulfide saturation in the formation of a Cu-and Au-rich magma: Insights from the platinum group element geochemistry of Niuatahi-Motutahi lavas, Tonga Rear Arc. Journal of Petrology 56(1), 59-81.

Park, J. W., Campbell, I. H. \& Kim, J. (2016). Abundances of platinum group elements in native sulfur condensates from the Niuatahi-Motutahi submarine volcano, Tonga rear arc: Implications for PGE mineralization in porphyry deposits. Geochimica et Cosmochimica Acta 174, $236-246$.

Park, J. W., Campbell, I. H., Malaviarachchi, S. P., Cocker, H., Hao, H. \& Kay, S. M. (2018). Chalcophile element fertility and the formation of porphyry $\mathrm{Cu} \pm \mathrm{Au}$ deposits. Mineralium Deposita, 1-14.

Paton, C., Hellstrom, J., Paul, B., Woodhead, J., \& Hergt, J. (2011). Iolite: Freeware for the visualisation and processing of mass spectrometric data. Journal of Analytical Atomic Spectrometry 26(12), 2508-2518.

Peach, C. L., Mathez, E. A. \& Keays, R. R. (1990). Sulfide melt-silicate melt distribution coefficients for noble metals and other chalcophile elements as deduced from MORB: Implications for partial melting. Geochimica et Cosmochimica Acta 54(12), 3379-3389.

Pearce, J. A. \& Stern, R. J. (2006). Origin of back-arc basin magmas: Trace element and isotope perspectives. Back-Arc Spreading Systems: Geological, Biological, Chemical, and Physical Interactions, 63-86.

Peucker-Ehrenbrink, B., Bach, W., Hart, S. R., Blusztajn, J. S. \& Abbruzzese, T. (2003). Rheniumosmium isotope systematics and platinum group element concentrations in oceanic crust from DSDP/ODP Sites 504 and 417/418. Geochemistry, Geophysics, Geosystems 4(7).

Ramos, V. A. (1989). The birth of southern South America. American Scientist 77(5), 444-450.

Reutter, K. J., Scheuber, E. \& Chong, G. (1996). The Precordilleran fault system of Chuquicamata, northern Chile: Evidence for reversals along arc-parallel strike-slip faults. Tectonophysics 259(1-3), 213-228.

Richards, J. P., Noble, S. R. \& Pringle, M. S. (1999). A revised late Eocene age for porphyry Cu magmatism in the Escondida area, northern Chile. Economic Geology 94(8), 1231-1247.

Richards, J. P., Boyce, A. J., \& Pringle, M. S. (2001). Geologic evolution of the Escondida area, northern Chile: A model for spatial and temporal localization of porphyry $\mathrm{Cu}$ mineralization. Economic Geology 96(2), 271-305.

Richards, J.P. (2003) Tectono-magmatic precursors for porphyry Cu-(Mo-Au) deposit formation. Economic Geology 98(8), 1515-1533.

Richards, J.P., Ullrich, T. \& Kerrich, R. (2006) The Late Miocene-Quaternary Antofalla volcanic complex, southern Puna, NW Argentina: Protracted history, diverse petrology, and economic potential. Journal of Volcanology and Geothermal Research 152, 197-239.

Richards, J. P. (2011a). Magmatic to hydrothermal metal fluxes in convergent and collided margins. Ore Geology Reviews 40(1), 1-26.

Richards, J. P. (2011b). High Sr/Y arc magmas and porphyry $\mathrm{Cu} \pm \mathrm{Mo} \pm$ Au deposits: just add water. Economic Geology 106(7), 1075-1081. 
Richards, J. P., Spell, T., Rameh, E., Razique, A. \& Fletcher, T. (2012). High Sr/Y magmas reflect arc

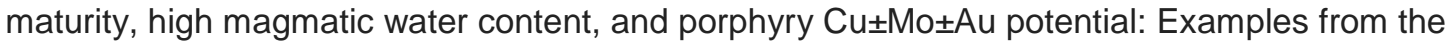
Tethyan arcs of central and eastern Iran and western Pakistan. Economic Geology 107(2), 295-332.

Richards, J. P., Jourdan, F., Creaser, R. A., Maldonado, G. \& DuFrane, S. A. (2013). Geology, geochemistry, geochronology, and economic potential of Neogene volcanic rocks in the Laguna Pedernal and Salar de Aguas Calientes segments of the Archibarca lineament, northwest Argentina. Journal of Volcanology and Geothermal Research 258, 47-73.

Richards, J. P. (2015). The oxidation state, and sulfur and Cu contents of arc magmas: implications for metallogeny. Lithos 233, 27-45.

Ripley, E. M., Brophy, J. G. \& Li, C. (2002). Copper solubility in a basaltic melt and sulfide liquid/silicate melt partition coefficients of $\mathrm{Cu}$ and Fe. Geochimica et Cosmochimica Acta 66(15), 2791-2800.

Romero, B., Kojima, S., Wong, C., Barra, F., Véliz, W. \& Ruiz, J. (2011). Molybdenite mineralization and Re-Os geochronology of the Escondida and Escondida Norte porphyry deposits, Northern Chile. Resource geology 61(1), 91-100.

Sá, J. H. S., Barnes, S. J., Prichard, H. M. \& Fisher, P. C. (2005). The distribution of base metals and platinum-group elements in magnetitite and its host rocks in the Rio Jacaré Intrusion, Northeastern Brazil. Economic Geology 100(2), 333-348.

Sillitoe, R. H. \& McKee, E. H. (1996). Age of supergene oxidation and enrichment in the Chilean porphyry copper province. Economic Geology 91(1), 164-179.

Sillitoe, R. H. (2010). Porphyry copper systems. Economic geology 105(1), 3-41.

Sláma, J., Košler, J., Condon, D. J., Crowley, J. L., Gerdes, A., Hanchar, J. M., Horstwood, M. S. A., Morris, G. A., Nasdala, L., Norberg, N., Schaltegger, U., Schoene, B., Tubrett, M. N. \& Whitehouse, M. J. (2008). Plešovice zircon-a new natural reference material for $\mathrm{U}-\mathrm{Pb}$ and $\mathrm{Hf}$ isotopic microanalysis. Chemical Geology 249(1-2), 1-35.

Smythe, D. J. \& Brenan, J. M. (2016). Magmatic oxygen fugacity estimated using zircon-melt partitioning of cerium. Earth and Planetary Science Letters 453, 260-266.

Spooner, E.T.C. (1993) Magmatic sulphide/volatile interaction as a mechanism for producing chalcophile element enriched, Archean Au-quartz, epithermal Au-Ag and Au skarn hydrothermal ore fluids. Ore Geology Reviews 7(5), 359-379.

Sun, S. S. \& McDonough, W. S. (1989). Chemical and isotopic systematics of oceanic basalts: implications for mantle composition and processes. Geological Society, London, Special Publications 42(1), 313-345.

Sun, W., Huang, R. F., Li, H., Hu, Y. B., Zhang, C. C., Sun, S. J., Zhang, L. P., Ding, X., Li, C. Y., Zartman, R. E. \& Ling, M. X. (2015). Porphyry deposits and oxidized magmas. Ore Geology Reviews 65, 97-131.

Takei, H., Yokoyama, T., Makishima, A. \& Nakamura, E. (2001). Formation and suppression of AIF3 during HF digestion of rock samples in Teflon bomb for precise trace element analyses by ICP-MS and ID-TIMS. Proceedings of the Japan Academy, Series B 77(1), 13-17.

Urqueta, E., Kyser, T. K., Clark, A. H., Stanley, C. R., \& Oates, C. J. (2009). Lithogeochemistry of the Collahuasi porphyry $\mathrm{Cu}-\mathrm{Mo}$ and epithermal $\mathrm{Cu}-\mathrm{Ag}(-\mathrm{Au})$ cluster, northern Chile: Pearce element ratio vectors to ore. Geochemistry: Exploration, Environment, Analysis 9(1), 9-17.

Valley, J. W. (2003). Oxygen isotopes in zircon. Reviews in mineralogy and geochemistry 53(1), 343385.

Valley, J. W., Lackey, J. S., Cavosie, A. J., Clechenko, C. C., Spicuzza, M. J., Basei, M. A. S., Bindeman, I. M., Ferreira, V. P., Sial, A. N., King, E. M., Peck, W. H., Sinha, A. K. \& Wei, C. S. (2005). 
4.4 billion years of crustal maturation: oxygen isotope ratios of magmatic zircon. Contributions to Mineralogy and Petrology 150(6), 561-580.

Wang, C. Y., Campbell, I. H., Allen, C. M., Williams, I. S., \& Eggins, S. M. (2009). Rate of growth of the preserved North American continental crust: evidence from $\mathrm{Hf}$ and $\mathrm{O}$ isotopes in Mississippi detrital zircons. Geochimica et Cosmochimica Acta 73(3), 712-728.

Wark, D. A., Hildreth, W., Spear, F. S., Cherniak, D. J., \& Watson, E. B. (2007). Pre-eruption recharge of the Bishop magma system. Geology 35(3), 235-238.

Warren, I., Simmons, S. F. \& Mauk, J. L. (2007). Whole-rock geochemical techniques for evaluating hydrothermal alteration, mass changes, and compositional gradients associated with epithermal AuAg mineralization. Economic Geology 102(5), 923-948.

Wiedenbeck, M. A. P. C., Alle, P., Corfu, F., Griffin, W. L., Meier, M., Oberli, F. V., Quadt, A. V., Roddick, J. C. \& Spiegel, W. (1995). Three natural zircon standards for U-Th-Pb, Lu-Hf, trace element and REE analyses. Geostandards and Geoanalytical Research 19(1), 1-23.

Wilkinson, J. J. (2013). Triggers for the formation of porphyry ore deposits in magmatic arcs. Nature Geoscience 6(11), 917.

Woodhead, J. D. \& Hergt, J. M. (2005). A preliminary appraisal of seven natural zircon reference materials for in situ Hf isotope determination. Geostandards and Geoanalytical Research 29(2), 183195.

Woodhead, J., Hergt, J., Shelley, M., Eggins, S. \& Kemp, R. (2004). Zircon Hf-isotope analysis with an excimer laser, depth profiling, ablation of complex geometries, and concomitant age estimation. Chemical Geology 209(1-2), 121-135.

Yoshikawa, M. \& Nakamura, E. (1993). Precise isotope determination of trace amounts of Sr in magnesium-rich samples. Journal of Mineralogy, Petrology and Economic Geology 88(12), 548-561.

Zindler, A. \& Hart, S. (1986). Chemical geodynamics. Annual review of earth and planetary sciences 14(1), 493-571.

\section{FIGURE CAPTIONS}

Fig. 1. Location map of the Escondida deposit and other major porphyry $\mathrm{Cu}$ deposits in Northern Chile (modified after Cocker et al., 2015).

Fig. 2. Geological map of the Escondida district, Northern Chile (modified after Richards et al., 2001 and Hervé et al, 2012).

Fig. 3. Selected photomicrographs of the regional diorites and ore-bearing porphyries of the Escondida district. (a) Plagioclase, orthopyroxene and weakly chlorite-altered clinopyroxene phenocrysts in a mafic diorite; cross-polarized light. (b) Plagioclase and partially chloritealtered hornblende phenocrysts with apatite inclusions in an evolved diorite; plane-polarized 
light. (c) Plagioclase and hornblende phenocrysts in the most evolved diorite; cross-polarized light. (d) Plagioclase, clinopyroxene and hornblende (with oxidized rims) phenocrysts in a mafic diorite; plane-polarized light. (e) Magnetite showing ilmenite exsolution lamellae in a mafic diorite (shown in panel a); reflected light. (f) Quartz with plagioclase, partially altered to sericite and kaolinite, in the Escondida porphyry; cross-polarized light. (g) Phenocrysts of biotite and plagioclase (partially altered to sericite and kaolinite) in the Zaldivar Llamo porphyry; plane-polarized light. Rounded sulfide inclusions in (h) clinopyroxene and (i) plagioclase phenocrysts in diorite, which are interpreted to be trapped sulfide melts; reflected light. Abbreviations: Plag = plagioclase $; \mathrm{Cpx}=$ clinopyroxene; $\mathrm{Hbl}=$ hornblende $; \mathrm{Chl}=$ chloride $; \mathrm{Ap}=$ apatite $; \mathrm{Qtz}=$ quartz $; \mathrm{Bt}=$ biotite $; \mathrm{Mag}=$ magnetite $; \mathrm{Ilm}=$ ilmenite $; \mathrm{SM}=$ sulfide melt inclusion.

Fig. 4. Selected whole rock major element variation diagrams for the regional diorites and ore-bearing porphyries of the Escondida district.

Fig. 5. Selected whole rock trace element variation diagrams for the regional diorites and orebearing porphyries of the Escondida district. The continuous short dashed line with an arrow in (h) is a trend line. The solid black arrow in (h) points to a value (1453 ppm), which is above the limit of the diagram.

Fig. 6. Multi-element plots normalized to the primitive mantle values of Sun and McDonough (1989), and REE patterns normalized to chondritic values of McDonough and Sun (1995), for the regional diorites and ore-bearing porphyries of the Escondida district.

Fig. 7. Plots of $\mathrm{Pd}, \mathrm{Pt}$, Ir and Re against $\mathrm{MgO}$ for the regional diorites and ore-bearing porphyries of the Escondida district. Open symbols are duplicate, and in some cases triplicate, analyses. Symbol sizes are larger than analytical errors. The $\mathrm{MgO}$ contents of the duplicate ore-bearing porphyries are too close to plot separately so that they have been moved slightly 
for plotting purposes in (b) and (c). Short dotted vertical lines link duplicate analyses. Horizontal dashed lines indicate the method detection limit (M.D.L.). Solid arrows indicate data below M.D.L. The continuous black dashed lines with arrows are trend lines of regional diorites. The blue short dashed line is a mixing line between primitive arc magma ( $9 \mathrm{wt} \%$ $\mathrm{MgO}$ and $10 \mathrm{ppb} \mathrm{Pd}$ ) and evolved magma (2.5 wt.\% $\mathrm{MgO}$ and $0.02 \mathrm{ppb} \mathrm{Pd}$ ). The blue circle symbol indicates the evolved magma and the blue arrow points to the primitive magma which is out of the limit of this diagram. The dark grey dashed line with arrow on (a) is a modelled trend line using $\mathrm{R}^{\prime}=5000$ for Pd (see the text for details).

Fig. 8. Plots of $\left({ }^{87} \mathrm{Sr} /{ }^{86} \mathrm{Sr}\right)_{\mathrm{i}}$ against $\left({ }^{143} \mathrm{Nd} /{ }^{144} \mathrm{Nd}\right)_{\mathrm{i}},\left({ }^{207} \mathrm{~Pb} /{ }^{204} \mathrm{~Pb}\right)_{\mathrm{i}}$ against $\left({ }^{206} \mathrm{~Pb} /{ }^{204} \mathrm{~Pb}\right)_{\mathrm{i}}$, and $\left({ }^{208} \mathrm{~Pb} /{ }^{204} \mathrm{~Pb}\right)_{\mathrm{i}}$ against $\left({ }^{206} \mathrm{~Pb} /{ }^{204} \mathrm{~Pb}\right)_{\mathrm{i}}$ for the regional diorites and ore-bearing porphyries of the Escondida district. The position of northern hemisphere reference line (NHRL) is shown on the $\mathrm{Pb}$ isotope plots (Hart, 1984). The bulk silicate earth value (BSE) is from Allègre et al. (1988). The mantle reservoirs from Zindler and Hart (1986) are plotted as: DM, depleted mantle; EMI and EMII, enriched mantle; MORB, mid-ocean ridge basalt; HIMU, mantle with high $\mathrm{U} / \mathrm{Pb}$ ratio; PREMA, frequently observed prevalent mantle composition. Panel (a) shows the model for mixing between primitive intraoceanic arc magma and the average composition of regional Paleozoic basement. The squares on the mixing lines indicate the weight percentage of the crustal component in the mixture. The $\mathrm{Sr}-\mathrm{Nd}$ isotope compositions of primitive intraoceanic arc magma are from Hawkesworth et al. (1993), and the regional Paleozoic basement is from Lucassen et al. (1999, 2001, 2004) and Richards et al. (2013) (excluding metabasites, which are not expected to be remelted by the intermediate or felsic magmas).

Fig. 9. Zircon $\mathrm{Ce}^{4+} / \mathrm{Ce}^{3+}$ ratios against weighted mean (a) U-Pb zircon ages and (b) temperature for the regional diorites (IM119, IM8, IM10 and IM69) and ore-bearing 
porphyries (Escondida porphyry: ESC2 and ESC3; Escondida Rhyolitic porphyry: ESC1; Zaldivar Llamo porphyry: ZAL1 and ZAL4).

Fig. 10. Zircon U-Pb age plotted against (a) $\delta^{18} \mathrm{O}$ and (b) $\varepsilon \mathrm{Hf}(\mathrm{t})$ values for the regional diorites (IM8, IM10 and IM69) and ore-bearing porphyries (Escondida porphyry: ESC2 and ESC3; Escondida Rhyolitic porphyry: ESC1; Zaldivar Llamo porphyry: ZAL1 and ZAL4) of the Escondida district. Short dashed horizontal lines in (a) indicate the compositional range of igneous zircons in equilibrium with primitive magma of mantle origin $\left(\delta^{18} \mathrm{O}=5.3 \pm 0.6 \%\right.$, 2б; Valley, 2003; Valley et al., 2005).

Fig. 11. Oxidation states plotted against temperature for the regional diorites (IM119, IM8, IM10 and IM69) and ore-bearing porphyries (Escondida porphyry: ESC2 and ESC3; Zaldivar Llamo porphyry: ZAL1 and ZAL4). Oxygen fugacities are calculated from Smythe and Brenan (2016), assuming an $\mathrm{H}_{2} \mathrm{O}$ content of 4 wt.\% for all samples. The magnetite-hematite (MH), nickel-nickel oxide, and fayalite-magnetite-quartz buffers are calculated from Chou (1978), Huebner and Sato (1970), and O’Neill (1987), respectively.

Fig. 12. Comparison between ore-bearing and barren suites on a plot of Pd against MgO. The dark blue arrows show the point of sulfide saturation for the Cadia $\mathrm{Au}-\mathrm{Cu}$, Northparkes $\mathrm{Cu}$ $\mathrm{Au}$, and $\mathrm{El} \mathrm{Abra} \mathrm{Cu}$ systems. Black arrows indicate data below method detection limit. Symbol sizes are larger than analytical errors. Data are from Cocker et al. (2015), Hao et al. (2017), Lowczak et al. (2018), and Park et al. (2018).

Fig. 13. Calculated enrichment factors for incompatible elements, $\mathrm{Cu}, \mathrm{Au}$ and $\mathrm{Pd}$ as a function of fractionation. Sulfide saturation is assumed to occur at $45 \%$ fractionation with the fraction of sulfide melt reaching 0.12 wt.\%. (a) R' >> D for all elements; (b) R' = 5000. The True partition coefficients (D) used for $\mathrm{Pd}, \mathrm{Au}$ and $\mathrm{Cu}$ are $10^{5}, 10^{4}$ and 1300 , respectively. See text for discussion. 
Fig. 14. Plot of $\mathrm{Pd} / \mathrm{MgO}$ against $\mathrm{Y}$ as an indicator of magma fertility to distinguish oreassociated from barren suites. Samples with $\mathrm{MgO}<2.5$ wt. $\%$ were plotted. For duplicate analyses, only the sample with the lowest Pd is plotted. Symbol sizes are larger than analytical errors. The black vertical arrows indicate samples with Pd concentrations below the detection limit, which are calculated using the detection limit. Data are from Cocker et al. (2015), Hao et al. (2017), Lowczak et al. (2018), and Park et al. (2018).

\section{TABLE CAPTIONS}

Table 1. PGE and Re analyses of the blank and TDB-1 standard in ppb.

Table 2. Whole-rock trace-element concentrations (in ppm) for the regional diorites and orebearing porphyries from the Escondida district.

Table 3. PGE and Re concentrations for the regional diorites and ore-bearing porphyries from the Escondida district.

Table 4. Sr-Nd-Pb isotopic compositions for the regional diorites and ore-bearing porphyries from the Escondida district.

Table 5. U-Pb zircon age data for the regional diorites and ore-bearing porphyries from the Escondida district. 


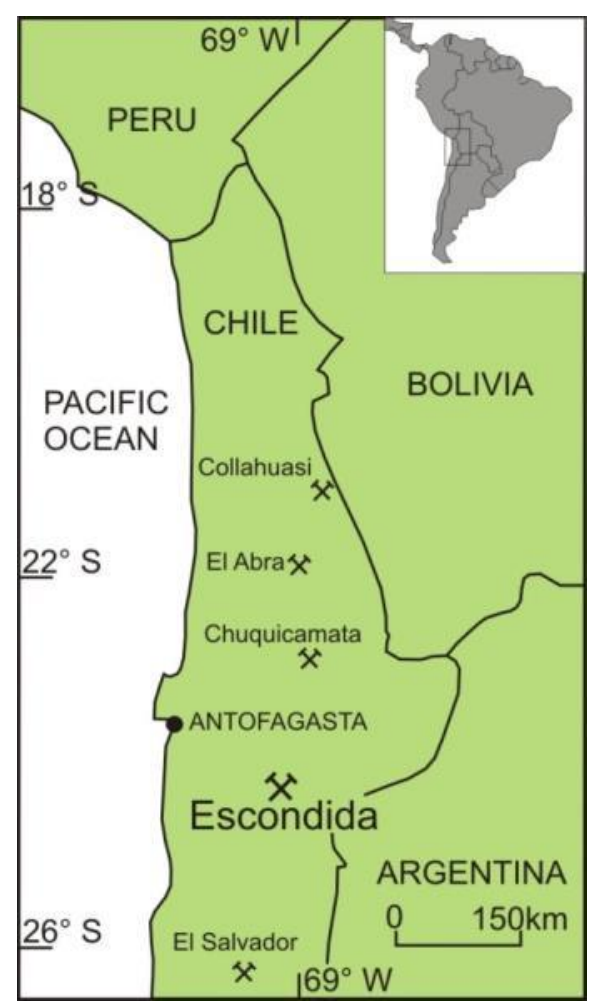

Fig. 1 


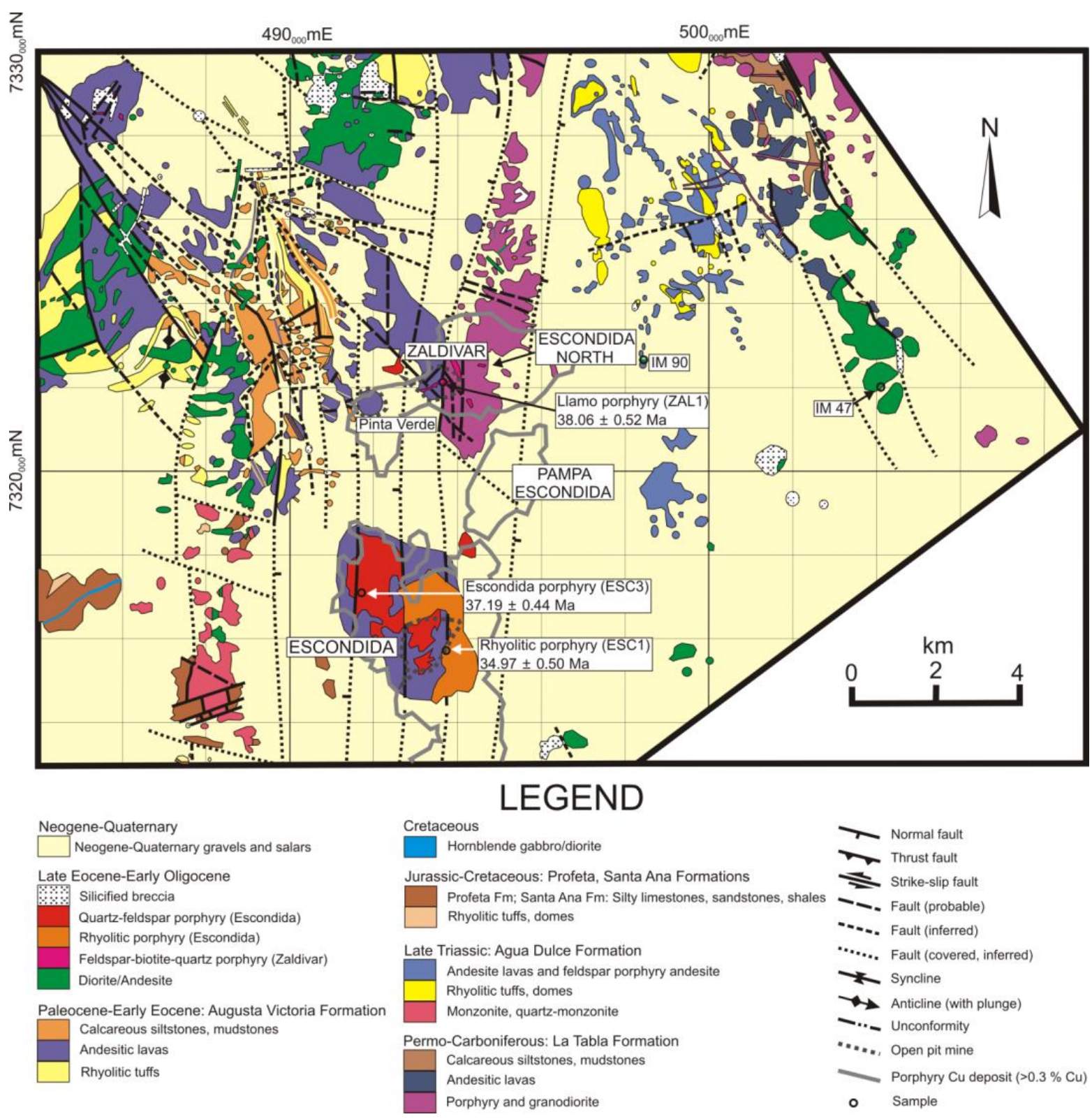

Fig. 2 

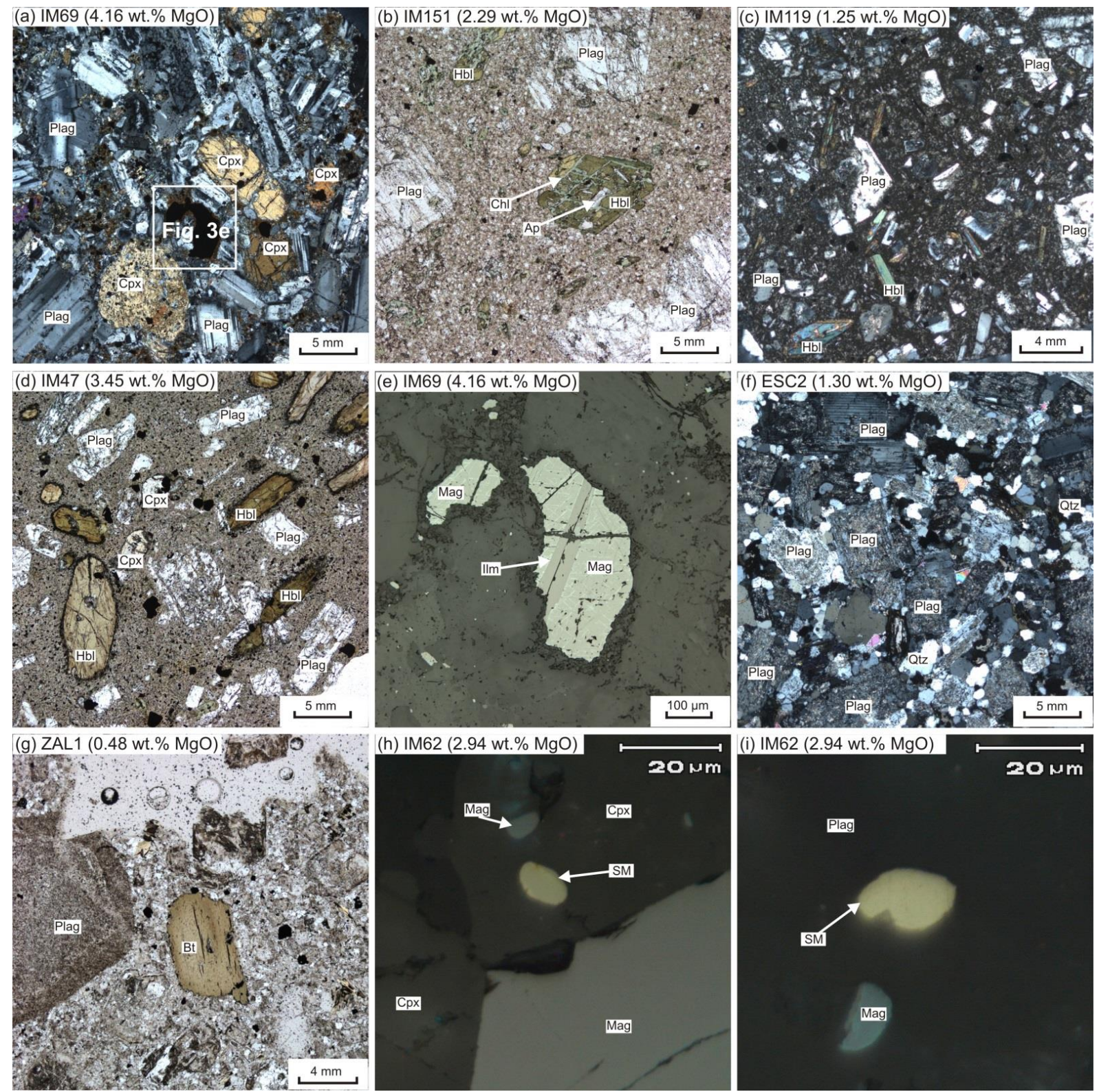

Fig. 3 

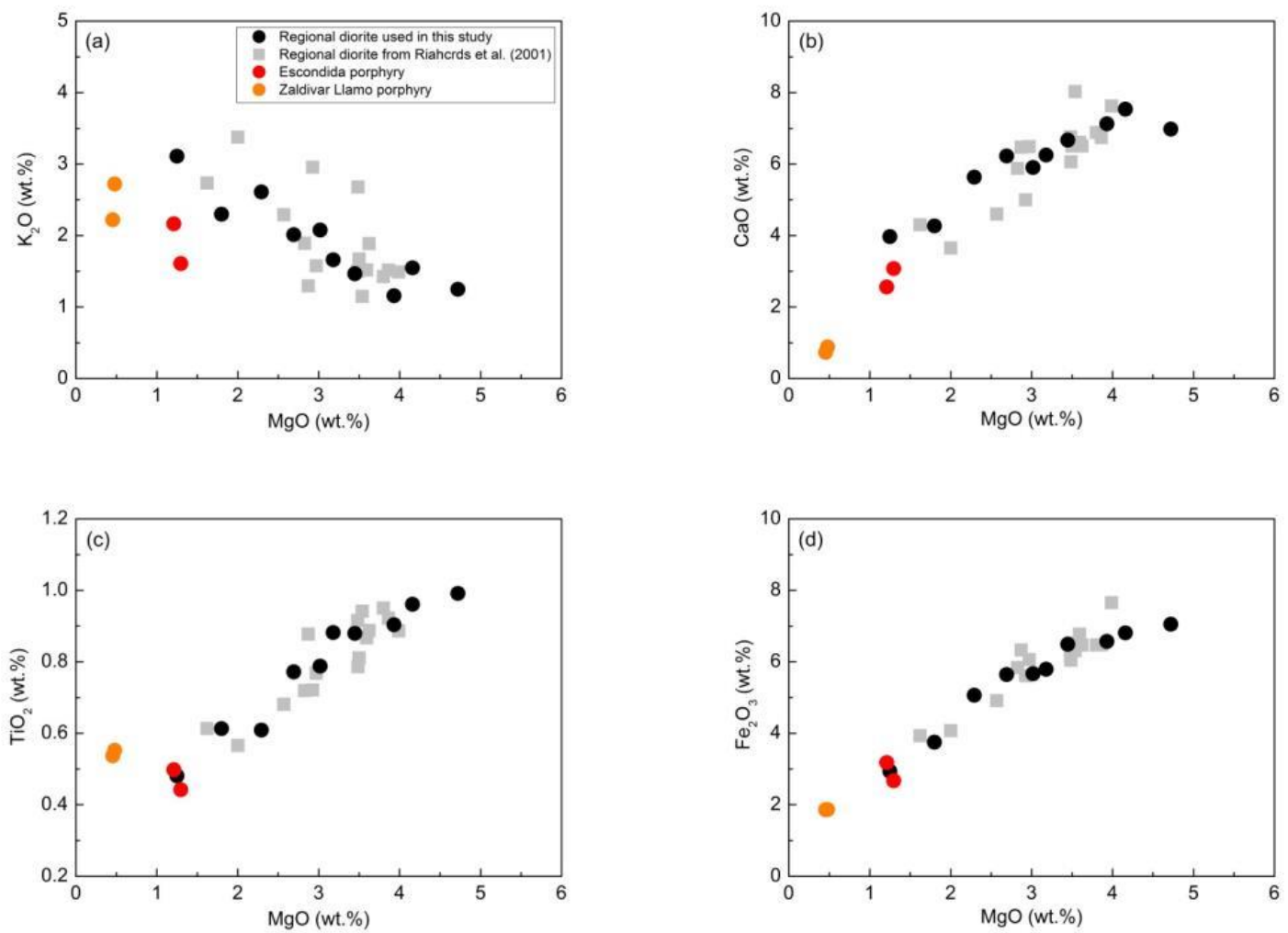

Fig. 4 

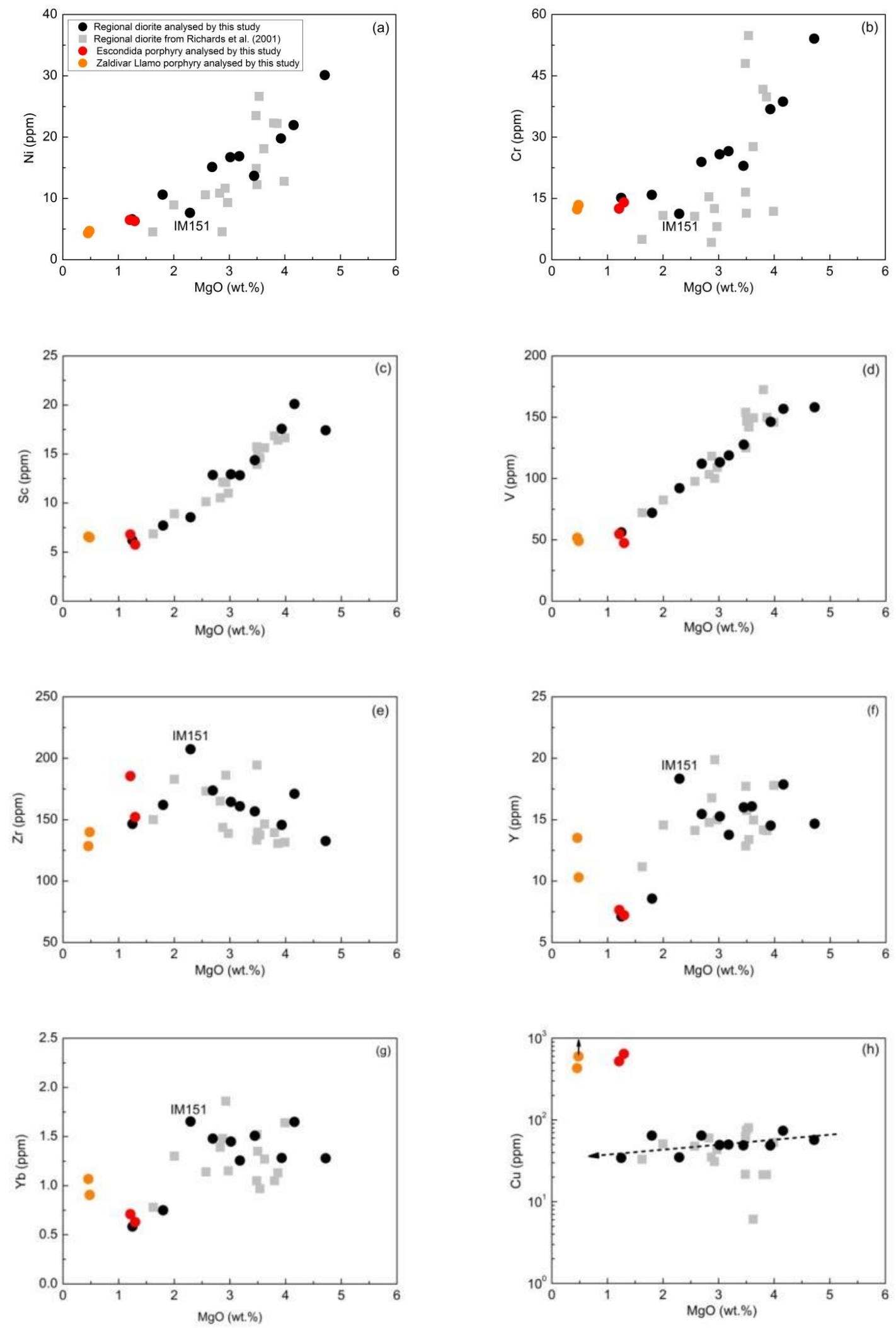

Fig. 5 

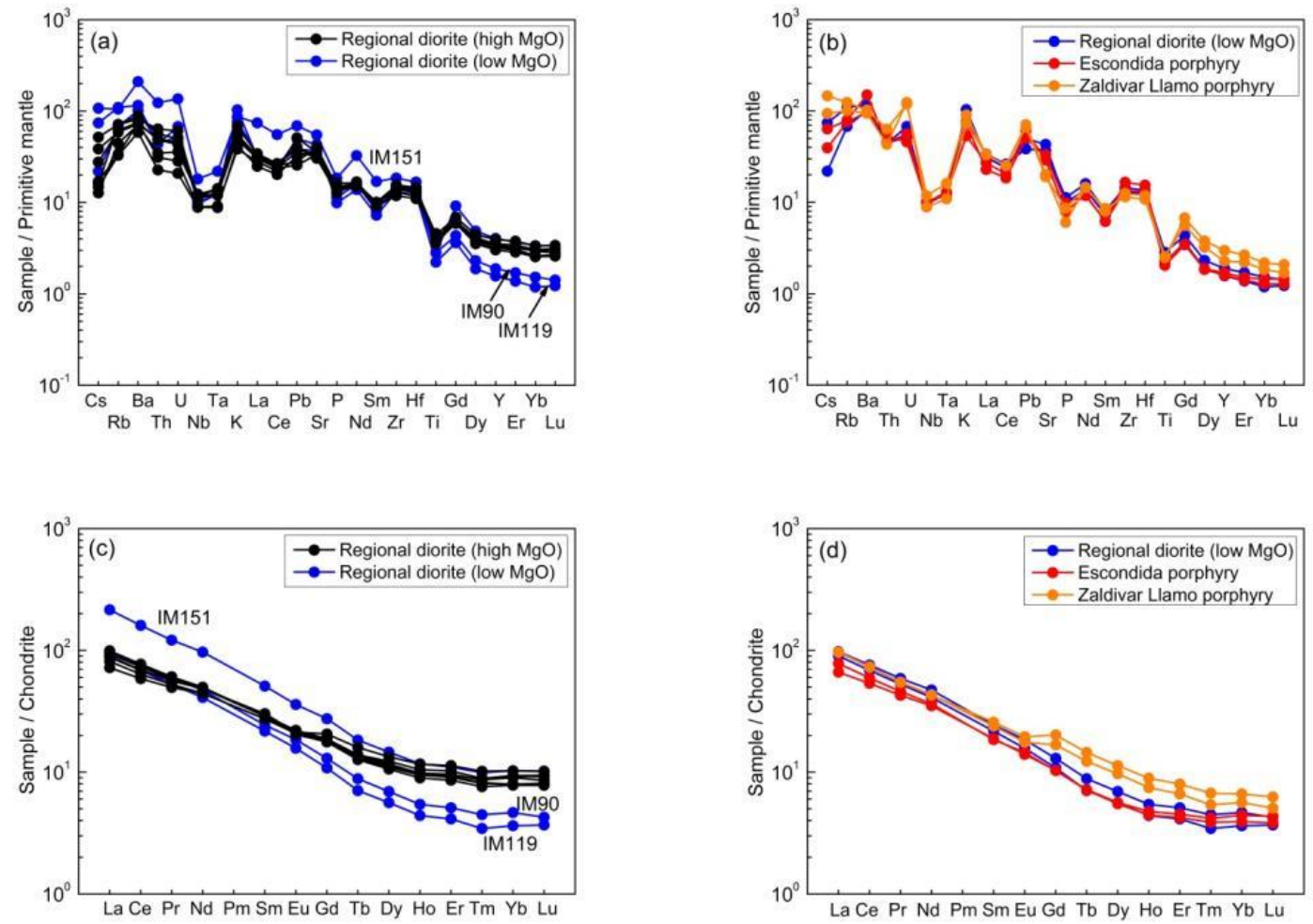

Fig. 6 

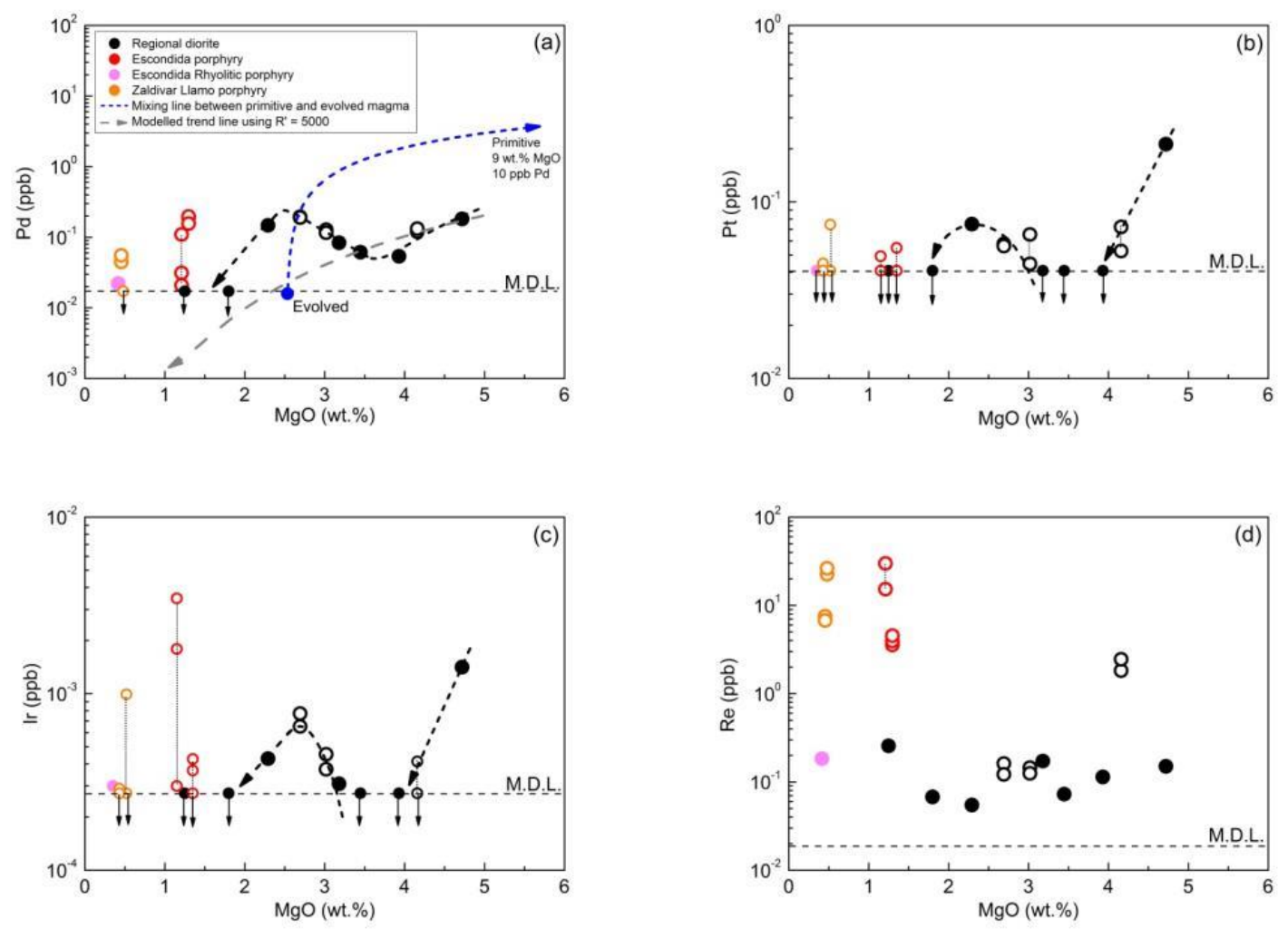

Fig. 7 

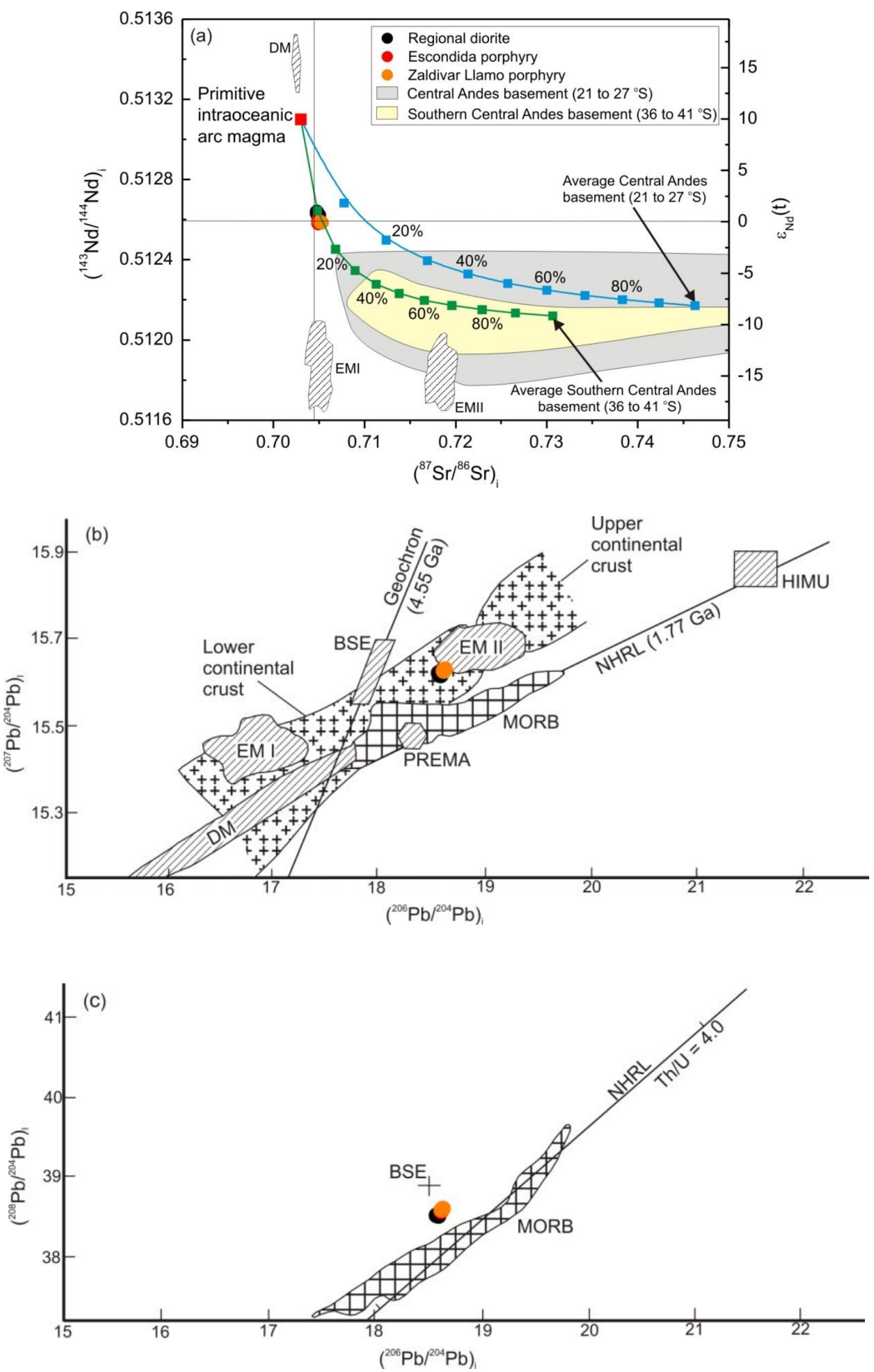

Fig. 8 

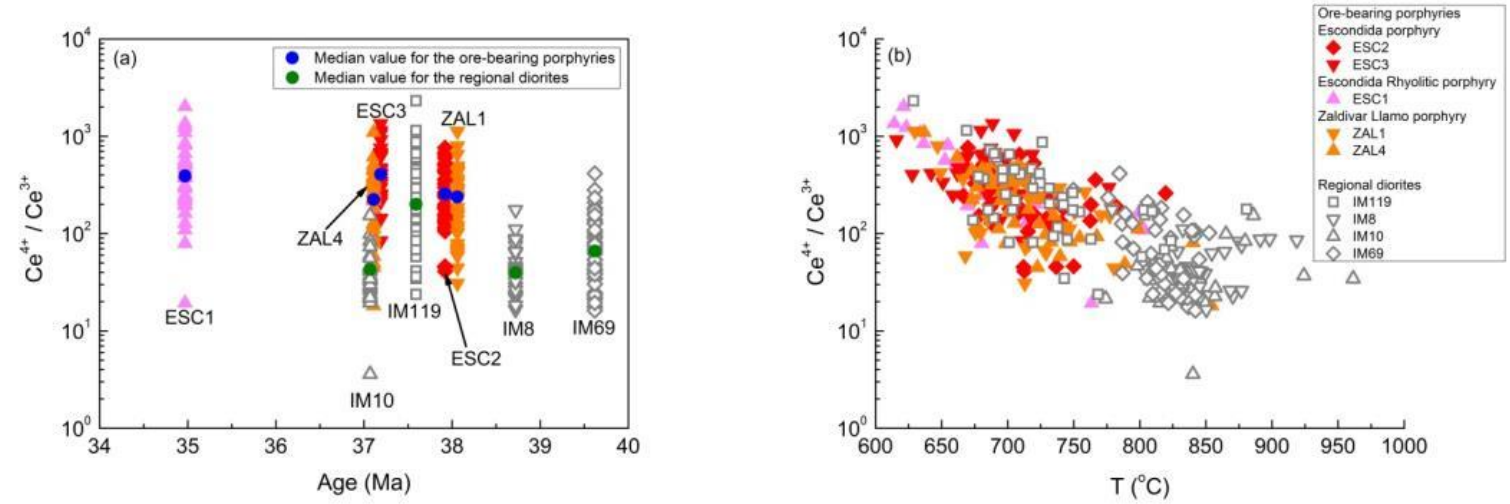

Fig. 9 

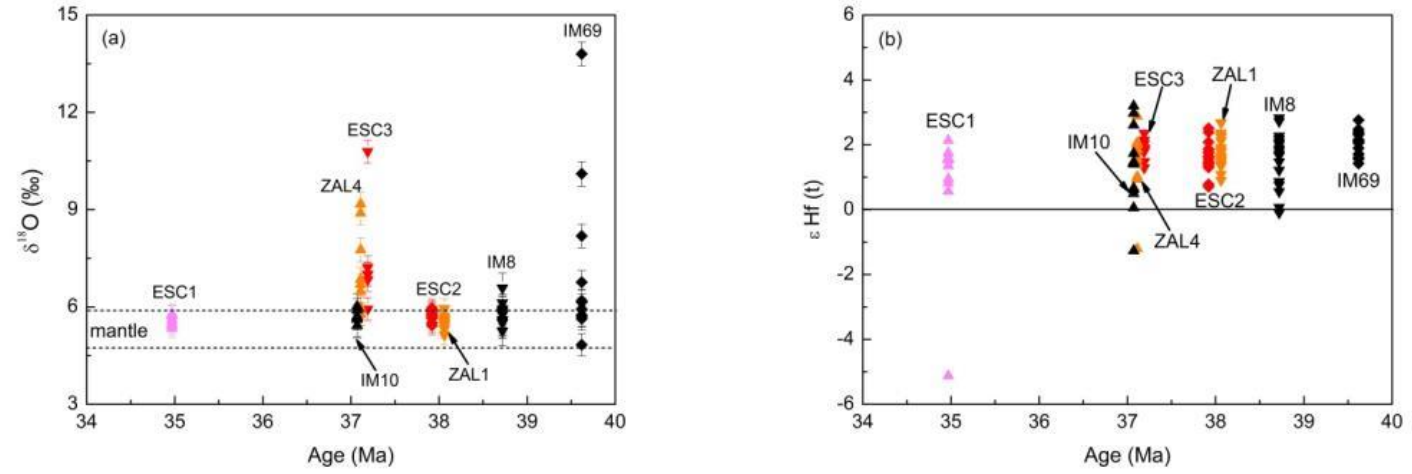

Fig. 10 

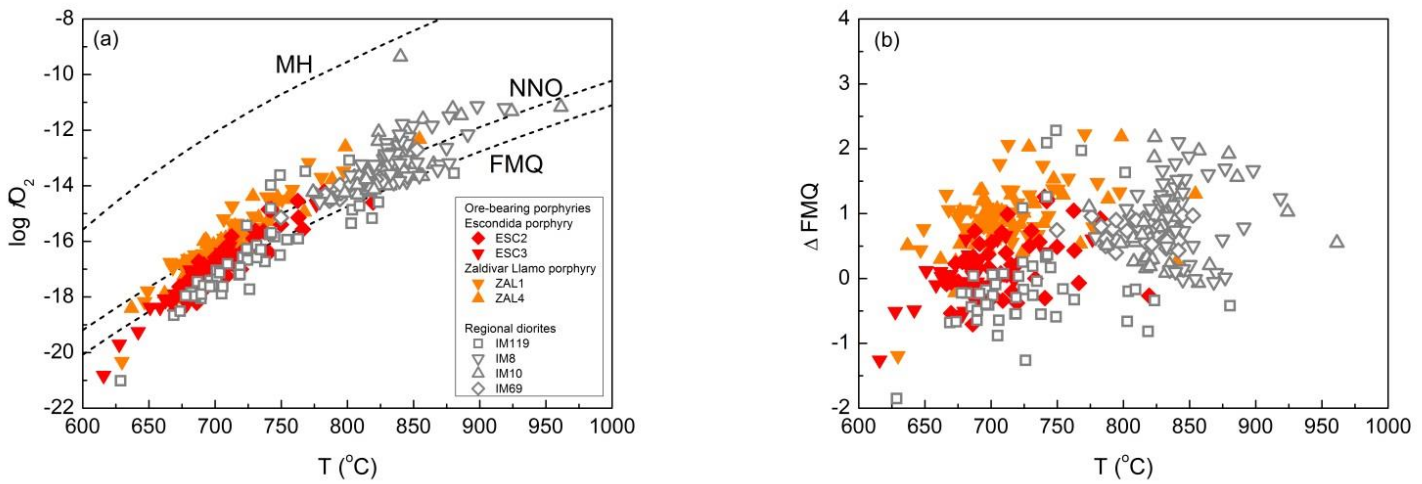

Fig. 11 


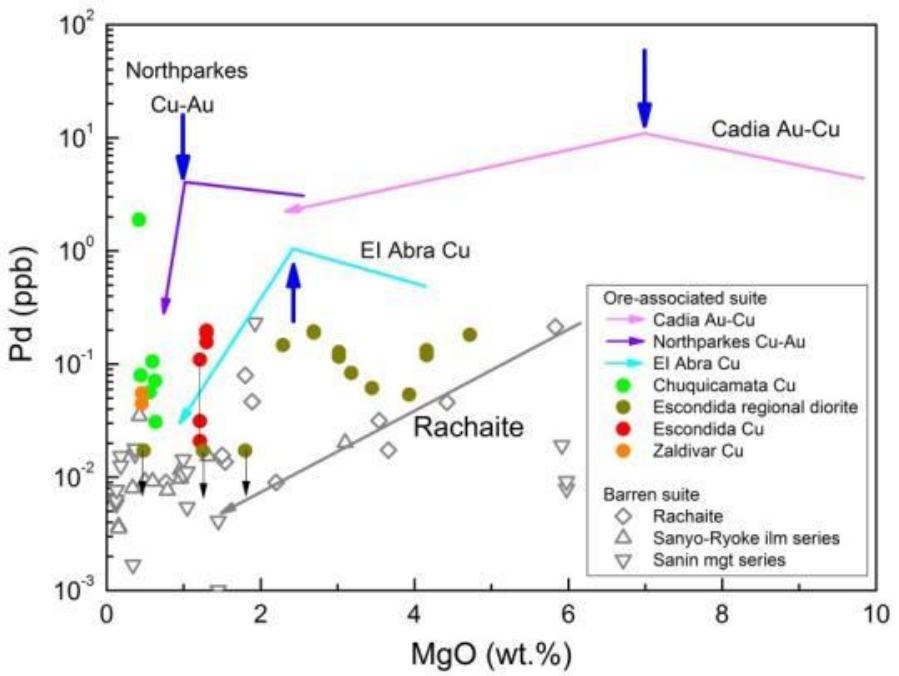

Fig. 12 

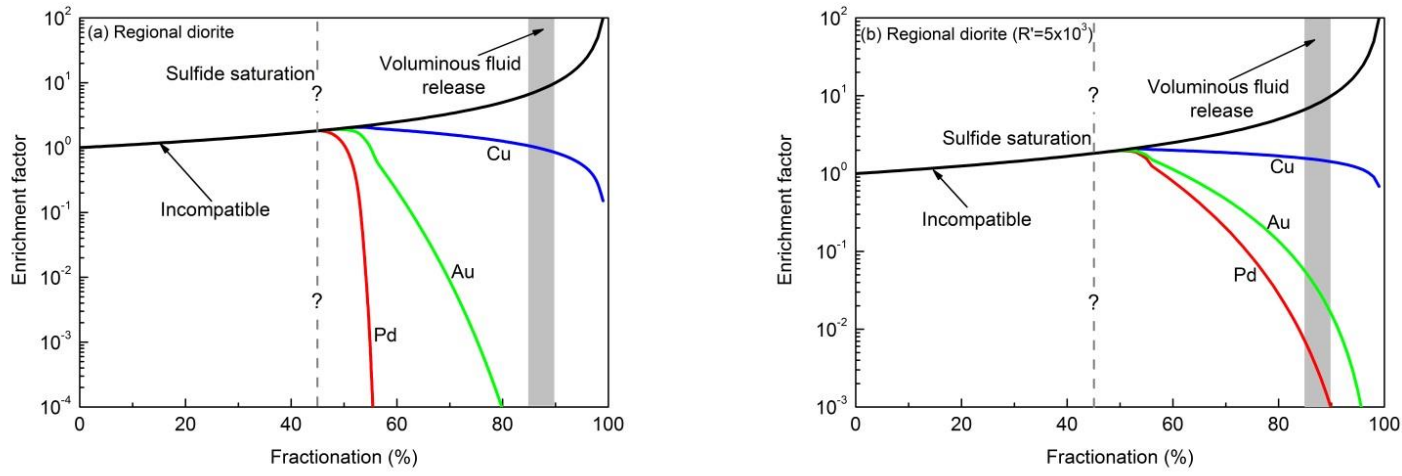

Fig. 13 


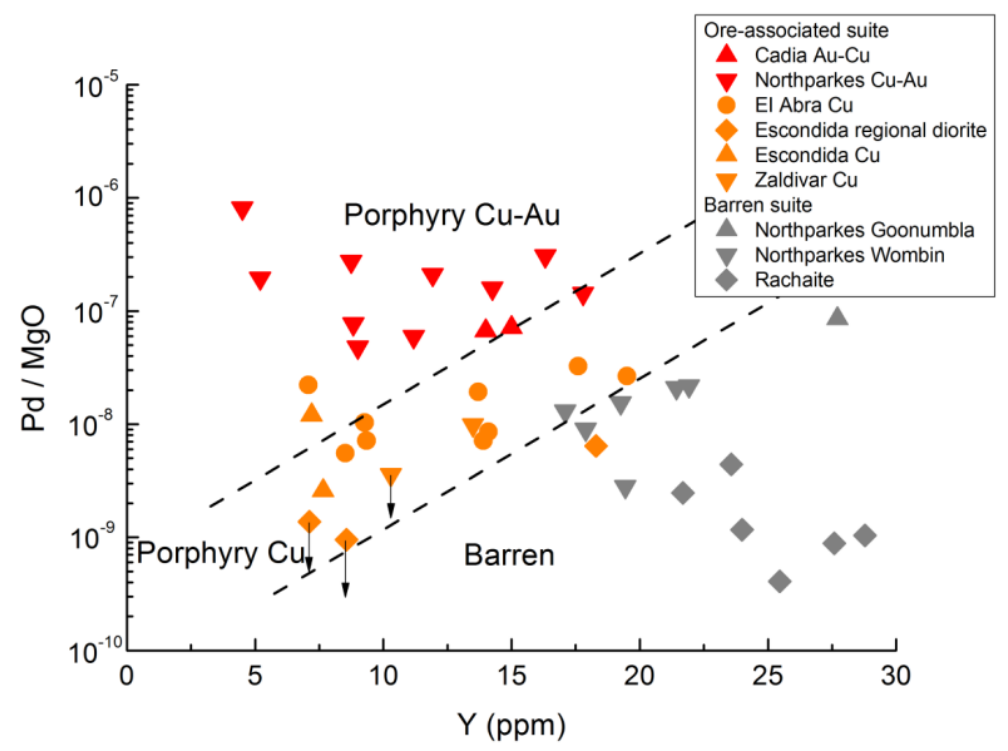

Fig. 14 